\title{
الأوقاف على المساجد في مصر 1849 - 1913م
}

مصطفى محمود على جمعة

$$
\text { إثراف }
$$

أ.د/ خلف عبد العظيم الميرى **

أ. أد /محمد عفيفى عبد الخالق

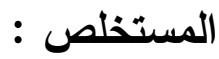

يعد الوقف عماد الحياة الدينية؛ فقد أمدّ المساجد بكل احتباجاتها ولوازمها، ووفر لها المصاريف اللازمة لأداء رسالتها، الأمر الذى أدى إلى تقوية الثعور الديني، ومن هنا كان مجال العبادات محط اهتمام الواقفين على لتى اختلاف انتماءاتهم الاجتماعية ومستوياتهم الاقتصادية، وقلما تخلو حجة وقف من تخصيص جزء من الريع

لوجه من وجوه إحياء شعائر الدين، ويلقى هذا البحث الضوء على دور الوقف في الحياة الدينية، وخاصة الدية

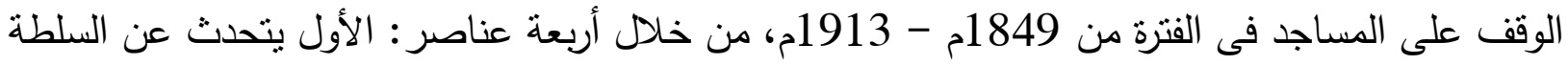
والأوقاف على المساجد، والثاني يتتاول دور أعضاء السلطة الحاكمة في الوقف على المساجد، والثالث

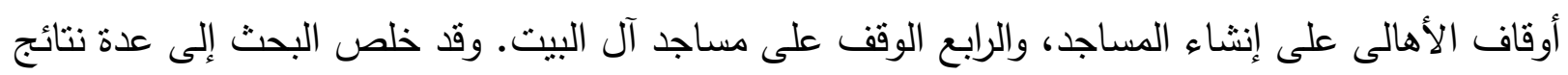

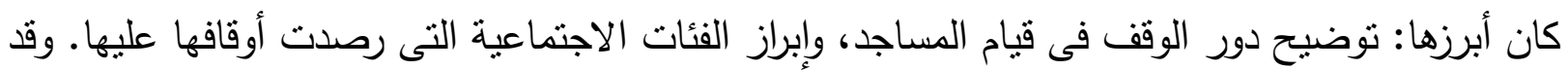

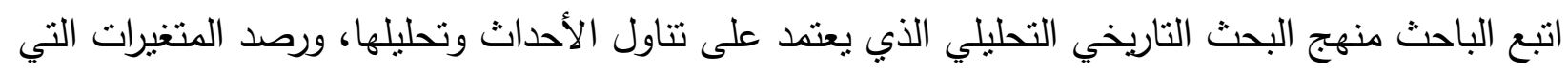
طرأت على مسيرة الوقف أثناء فترة البحث.

$$
\text { الكلمات المفتاحية : وقف - مسجد - إسماعيل - وثاثق - آل بيت }
$$

$$
\text { * باحث دكتوراه - قسم التاريخ - كلية البنات - جامعة عين شمس }
$$

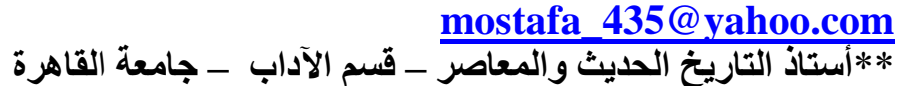

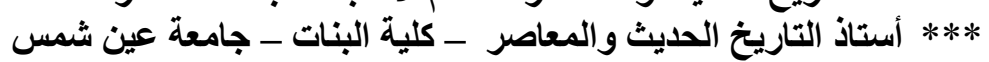


المسجد هو مكان السجود و إقامة الثعائر الدينية من صلاة وذكر وتسبيح وقر اعة قرآن .. وقد احتل

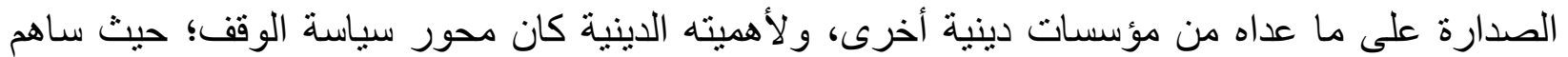

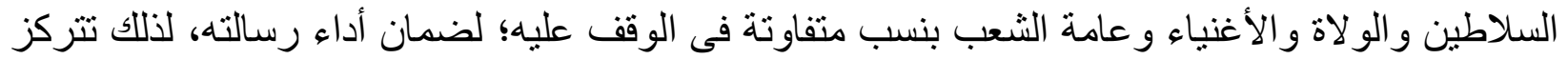

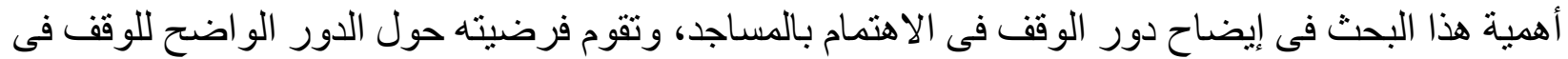

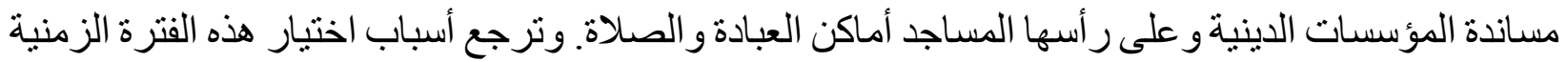

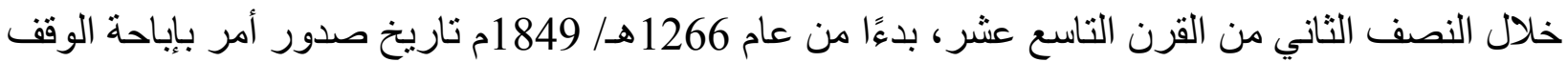

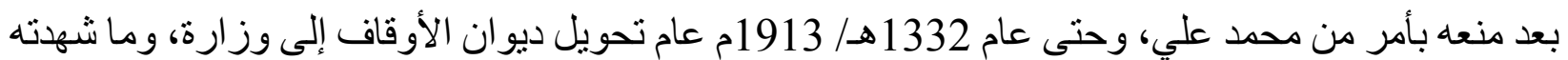
هذه الفترة من ازدهار في الوقف على على المساجد وتعمير ها و الإنفاق عليها.

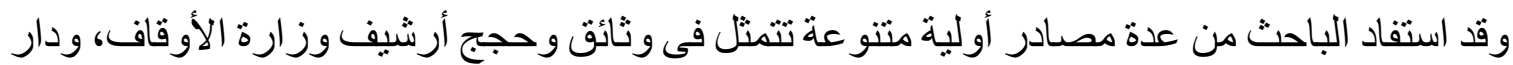

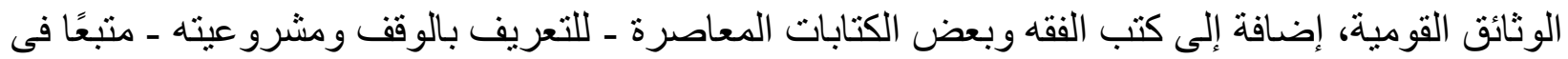

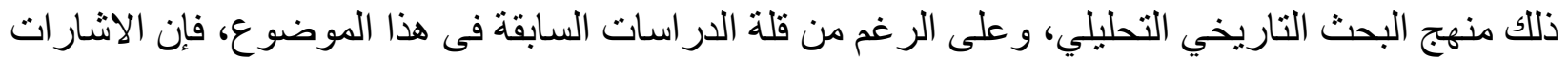

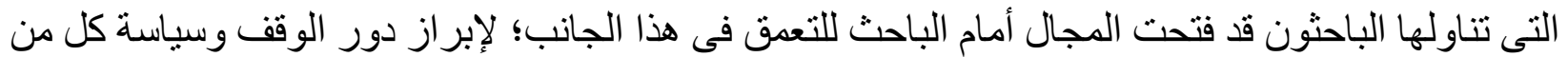

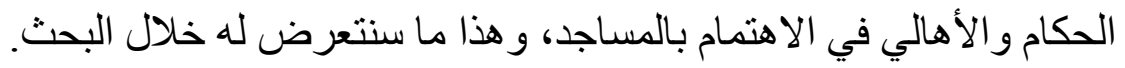
تعريف الوقف ومشرو الاهيته:

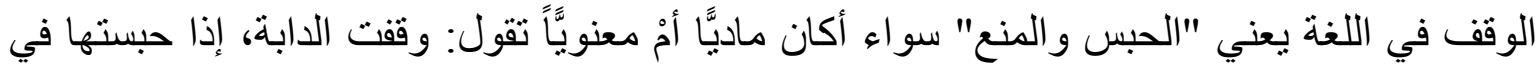

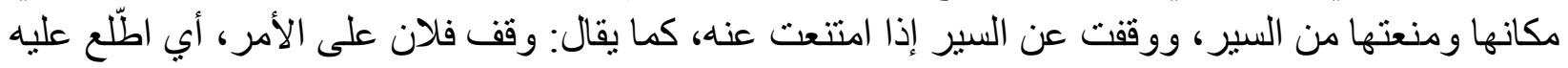

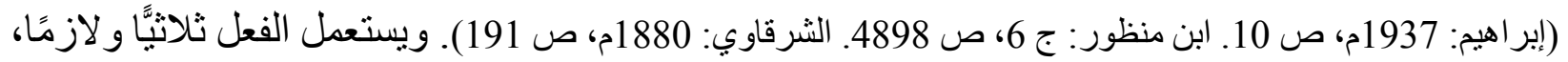

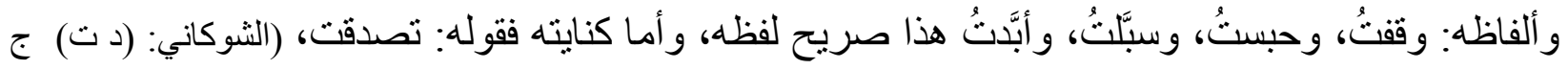

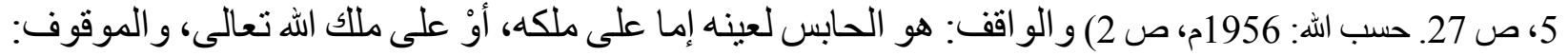

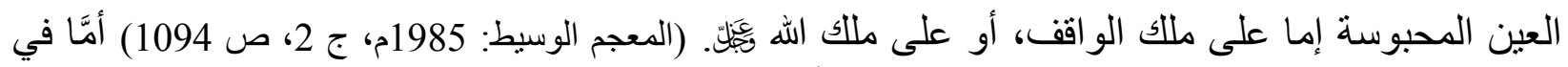

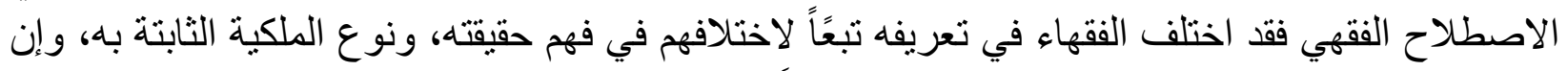

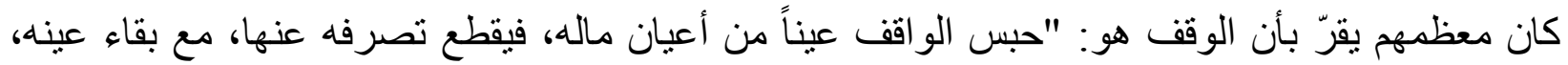

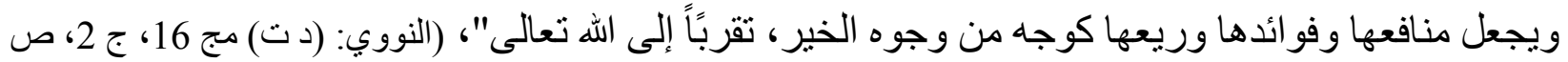

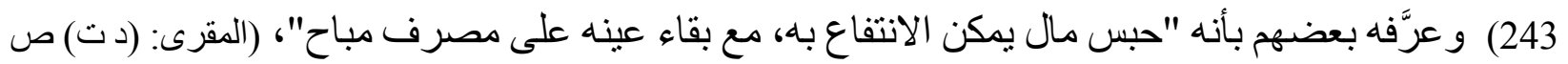

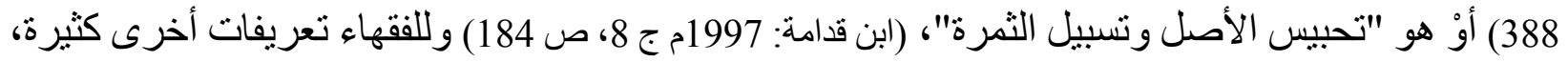
منها ما ذكره ابن حجر في "فتح الباري" وهو أنه "قطع التصرف في رقبة العين العين التي يدوم الانتفاع بها،

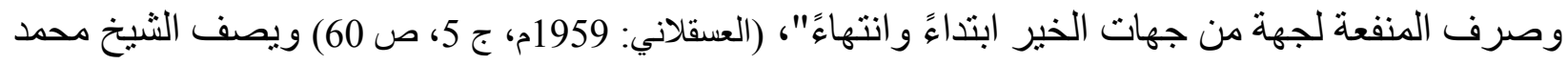
أبو زهرة هذا التعريف بأنه "أصدق تعريف مصور جات الصع لصور الوقف عند الفقهاء الذين قرروه" (أبو زهرة:

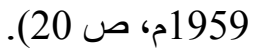


وقد استقر "مصطلح الوقف" فى التعريف الفقهي السابق منذ البدايات الأولى لظهوره في القرن الأول

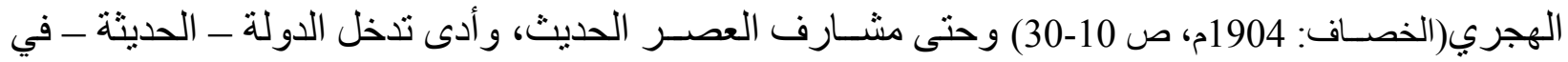

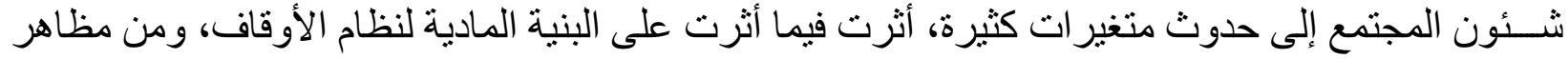

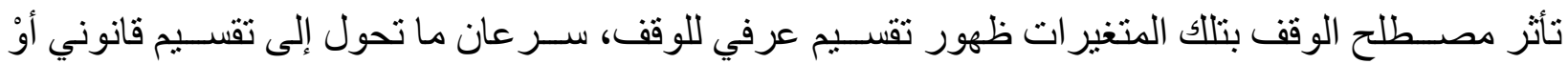

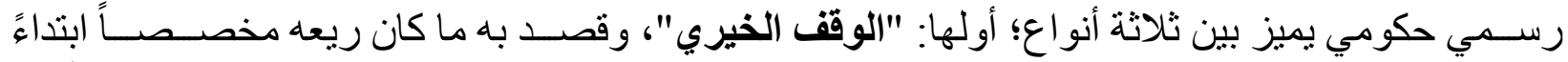

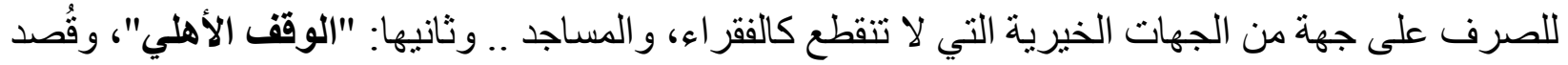

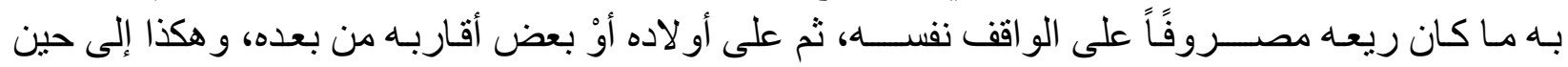

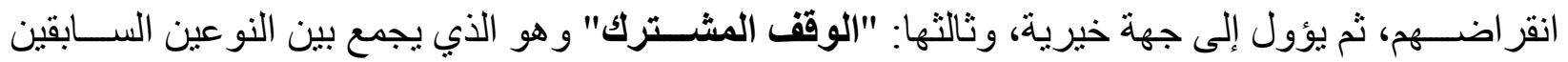

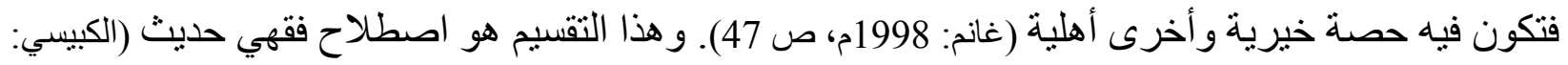

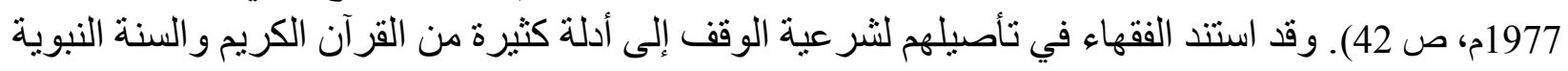

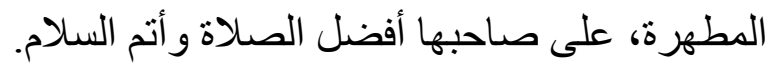

\section{1-السلطة والأوقاف على المساجد:}

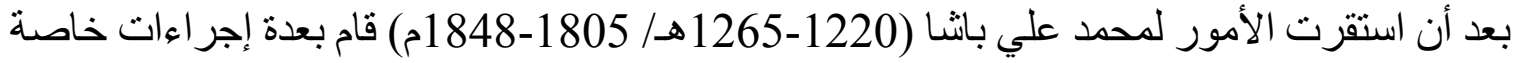

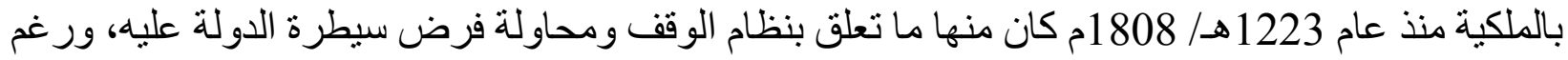

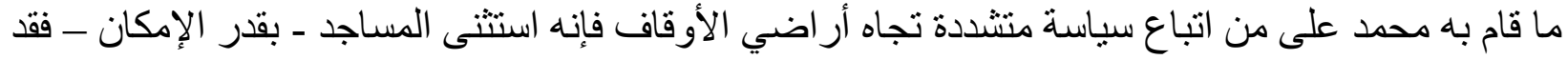

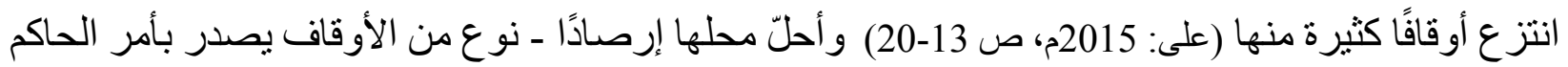

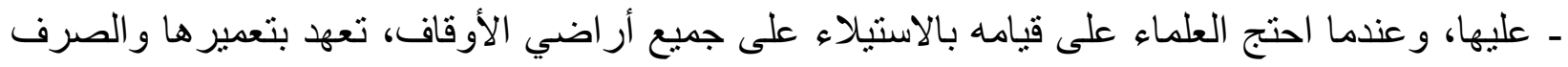

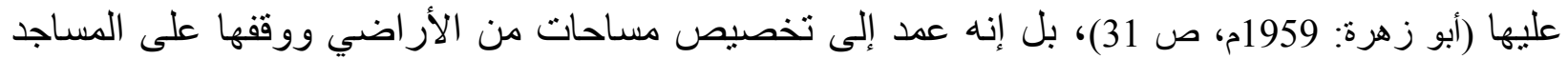

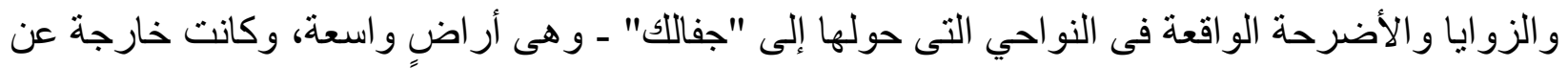

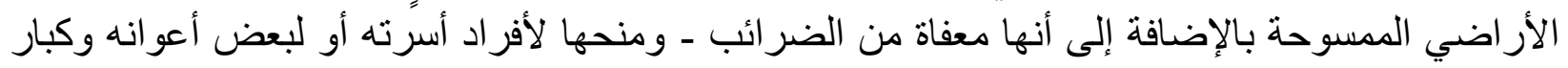

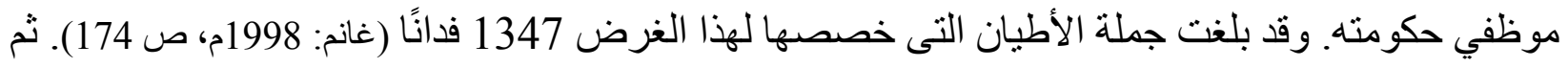

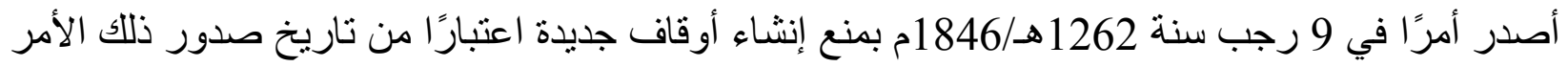

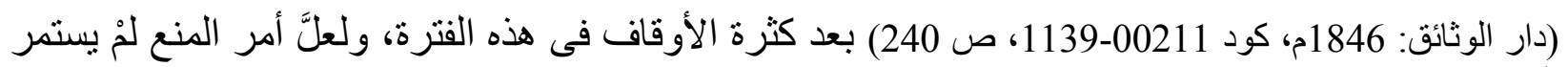

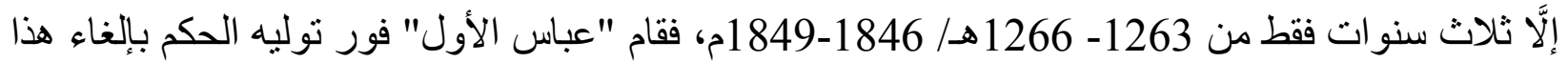

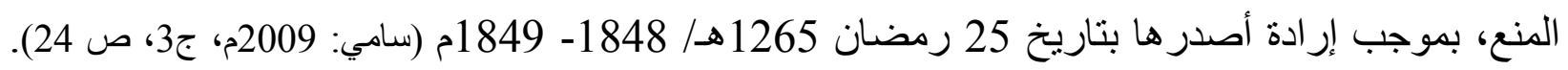

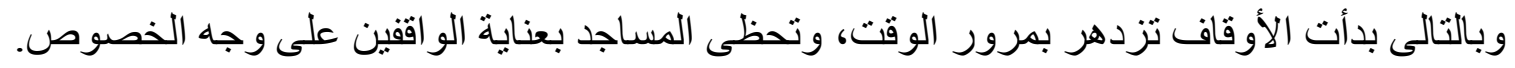

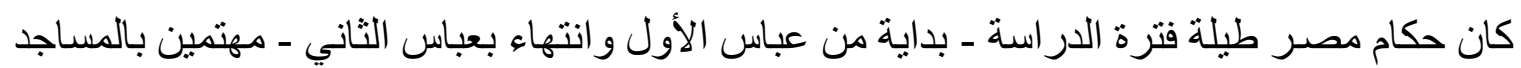

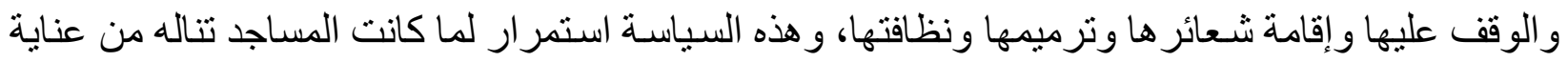

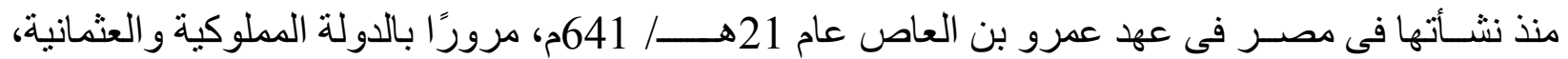

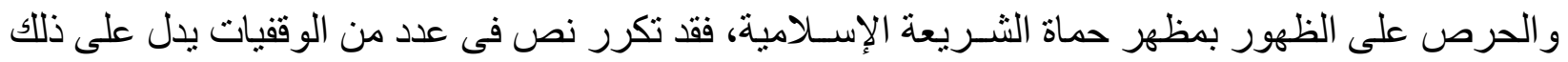


"حيث إن عمارة المسـاجد وإقامة الثـعائر الدينية من أقصسى مر غوبنا" (دار الوثائق: 1280هــــ محافظ الأبحاث،

محفظة 131).

كان عباس باشـا الأول (1265 - 1271 1271هــ/ 1848- 1854م) مهنمَّا بالمساجد وبمجرد توليه الحكم

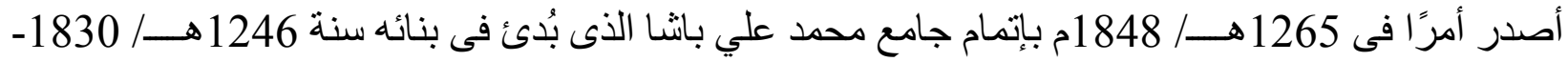

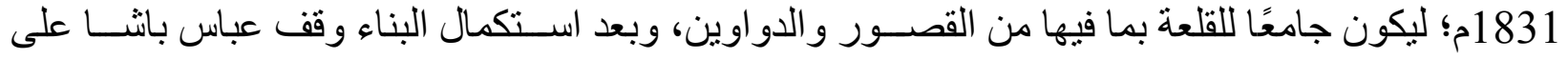
الجامع فى 9 رجب 1269 هـــ/ 1852م "جميع المبلغ المرتب بديوان الروزنامجة العامرة وقدره في كل سنة 150000 قرش .. يصـرف المبلغ المذكور المرصــ فى مصـالح المسـد وإقامة شـعائره الإسـلامية المعدور

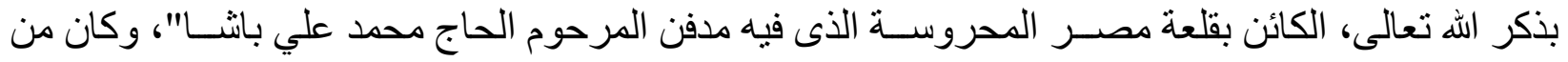

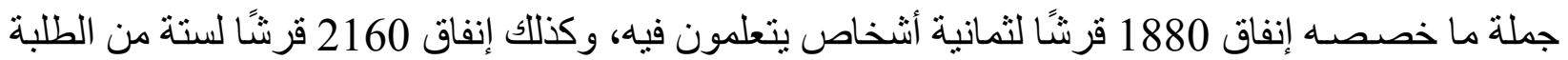

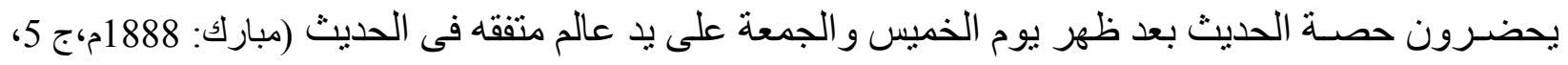
ص 82)، وكان هذا الجامع من أهم الجو امع التى بنيت فى النصف الأول من القرن التاسع عشر ، و واكتمل بناؤه

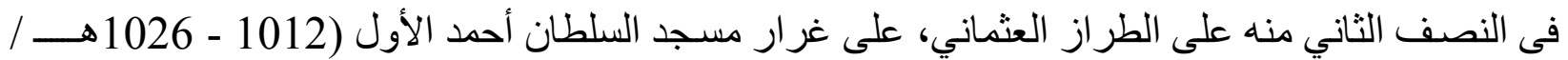
(Al - Asad, 1992, P43-52) (1617 - 1603 وقد وضـع عباس باثـا الحجر الأول لمسـد السيدة زينب بيده، و أقيم لذلك احتفال عظيم حضره كثير

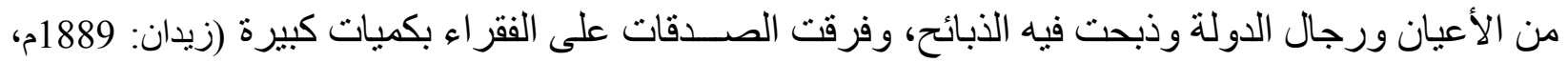

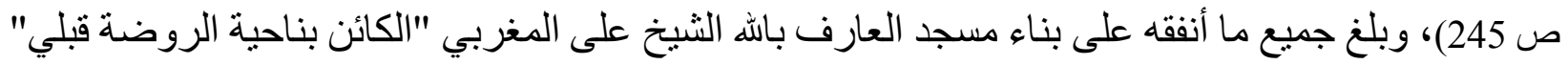

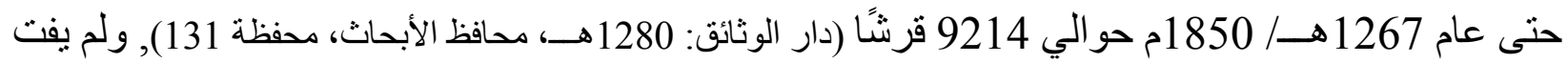

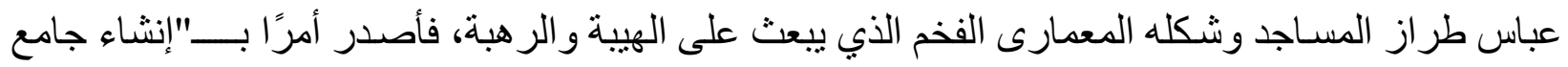

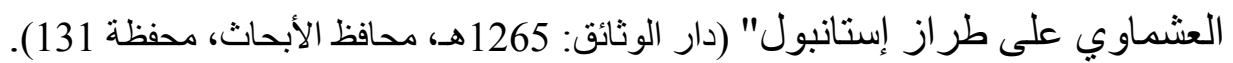

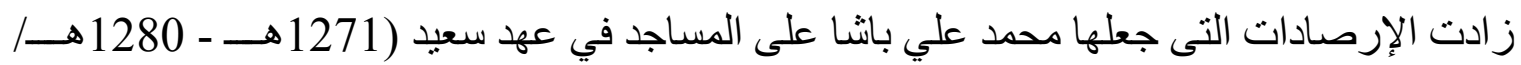

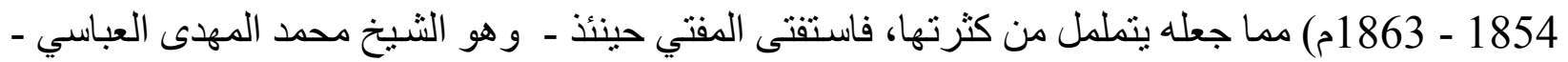

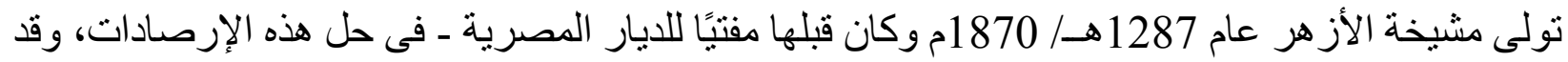

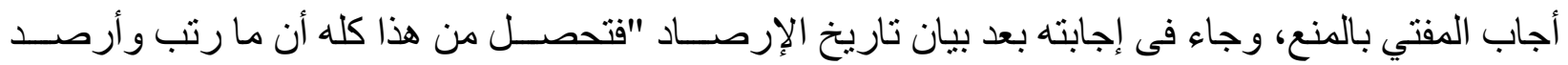

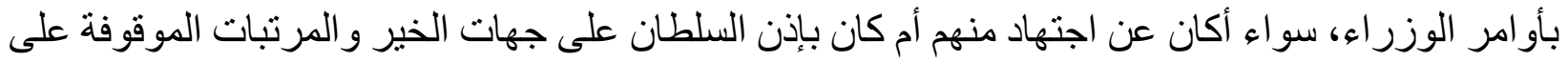

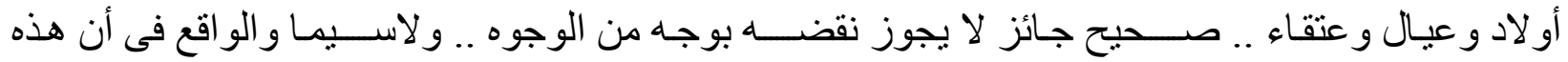

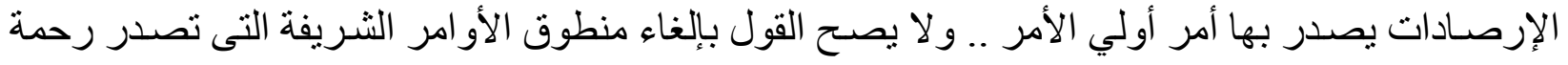

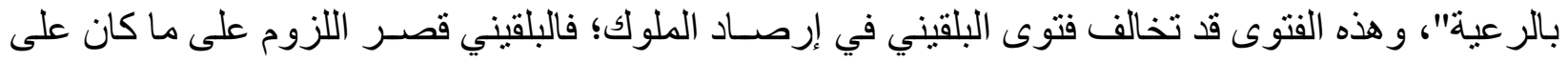
جهات عامة، ومنعه بالنسبة للأشـخاص، أما فتوى المهدي فإنها تلزم الإرصـاد كله، من غير تفرقة بين ما ها هو

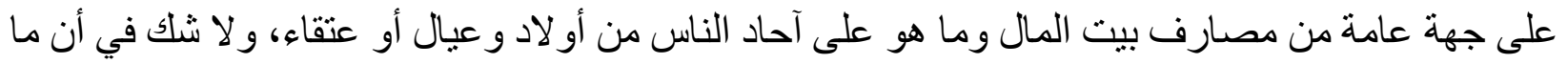
ذكره البلقيني هو الفقه، لأن الإرصـاد وتخصيص جزء هـ من أرض بيت المال على بعض مصار فهه، ومصـارفه 
جهات لا أثـخاص إلا إذا كان الأشـخاص ضــن جهة كالفقر اء أو اليتامي أو المرضـى (أبو زهرة: 1959م، ص

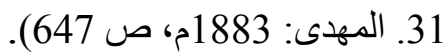

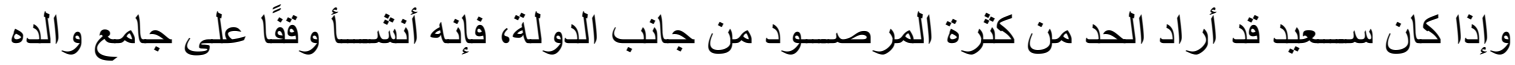
محمد علي باثـا بالقلعة في 25 الحجة 1273 هـــ/ 1856م "وقف الأطيان الرزقة التي بلا مال الإحباسية التي

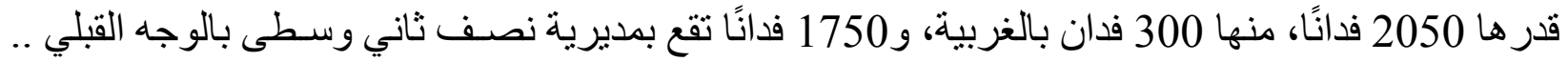

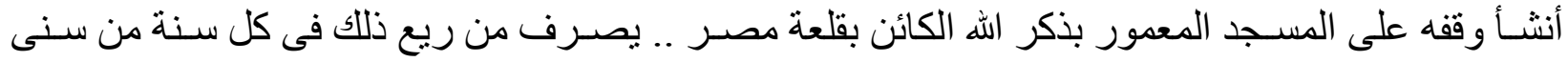

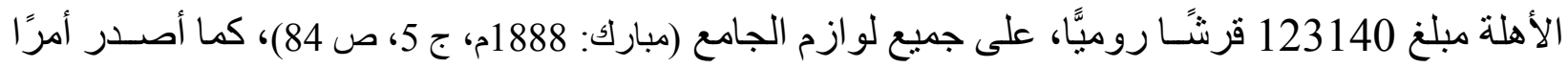

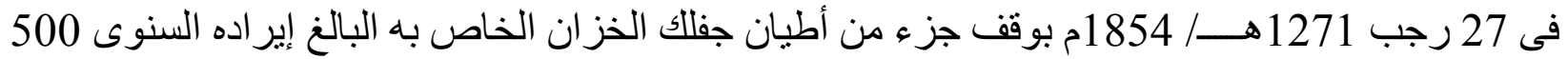
قرش لناظر وقف سبدي ونس، الموجود ضـريحه بالإسكندرية بدلا من الأرض التي أخذت منه بالقباري (دار

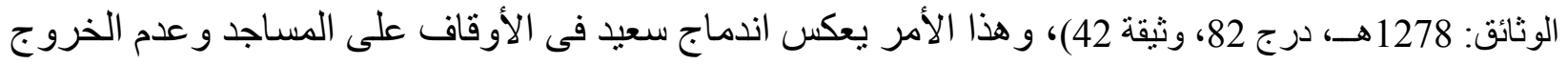

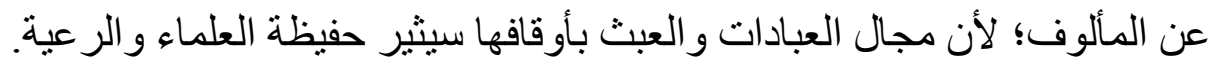
كان أثـهر أوقاف حكام مصر من أسرة محمد عَلي عَلَى النواحي الدينية وخاصة المساجد، وما بتعلق

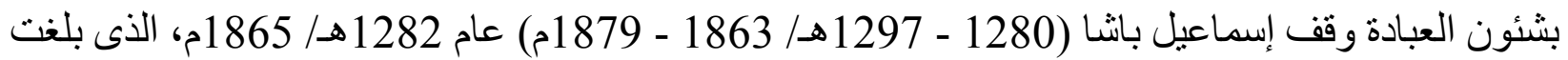

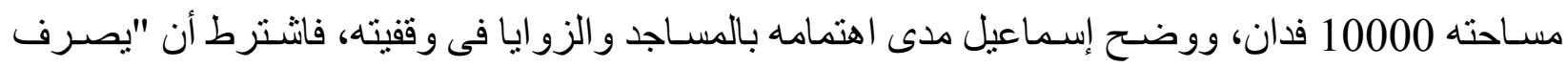

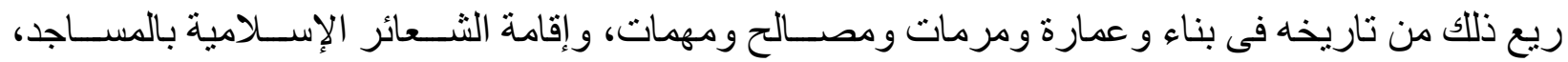
و المكاتب الكائنة بمصـر المحروســة التى لا ريع لها أصــلا، أو لها ريع لا يفي بالعمار ات، و إقامة الثـــائر

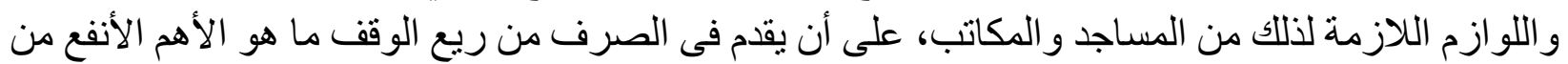

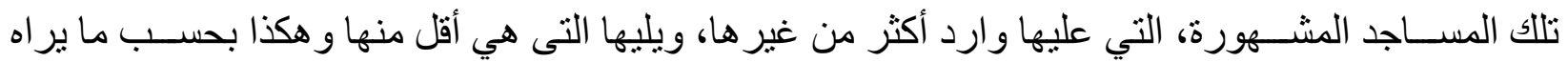

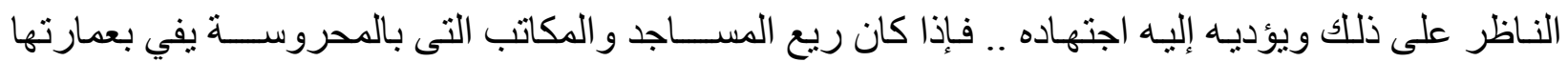

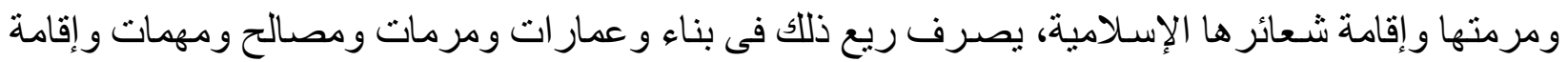

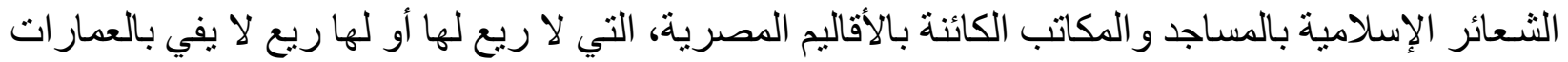

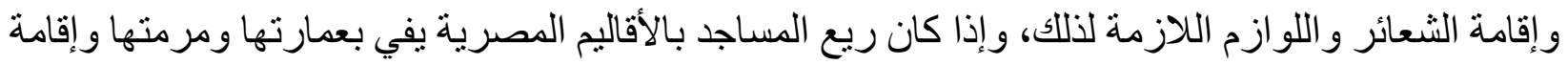
شــعائر ها الإســامية، يصـرف ريع ذلك للفقر اء و المســاكين و الأر امل و المنقطعين من المســلمين أينما كانوا

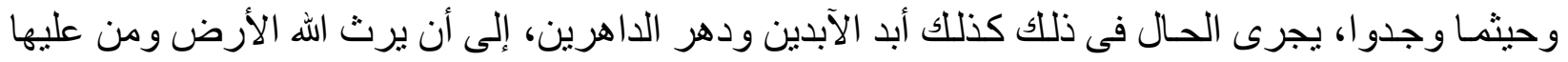

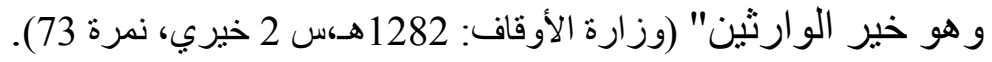

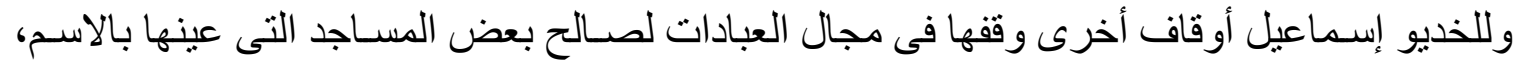
منها مسـاحة 150 فدانٍا لمسـد السيدة نفيسـة بالقاهرة، و60 فدانا لمسجد الثيخ الفولي بمدينة المنيا، بالإضـافة إلى بعض العقار ات المبنية وحصـة غير محددة فى مسـاحة 1090 فدانًا للصـرف على على مسجد الثيخ صـالح أبو

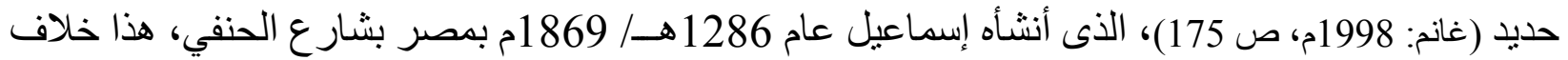

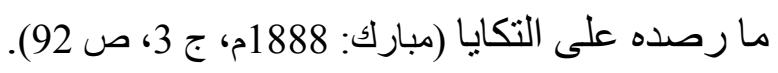




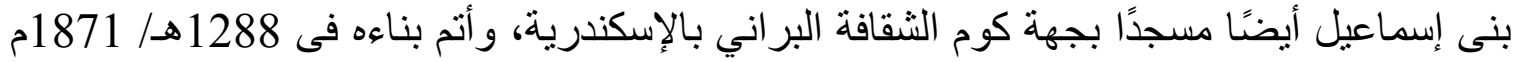

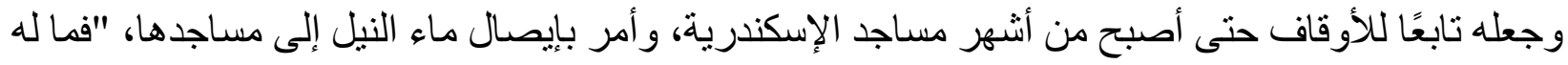

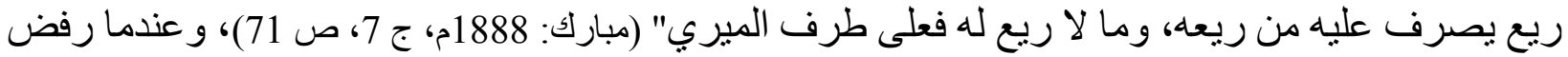

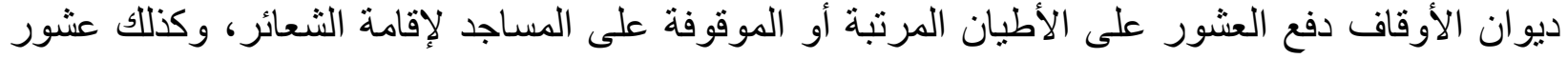

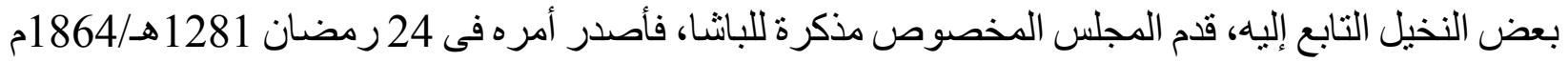

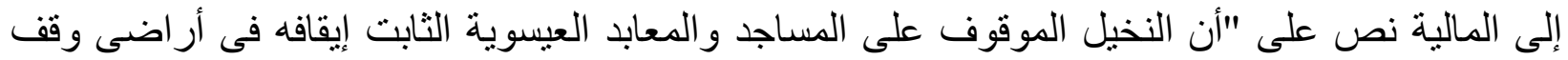

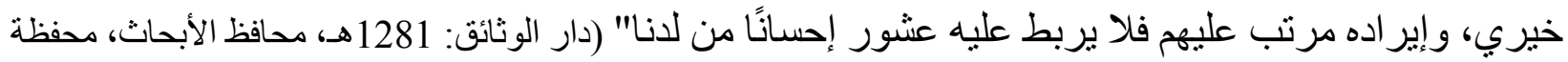

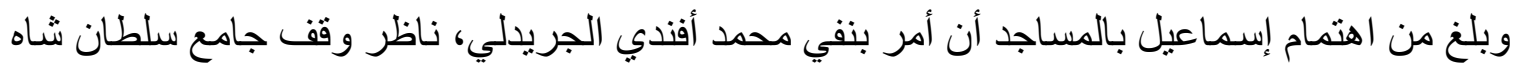

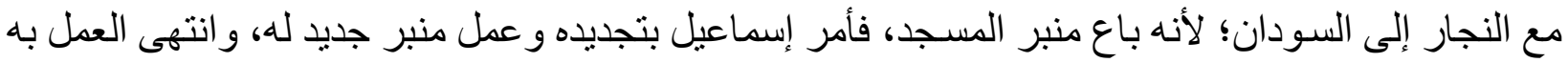

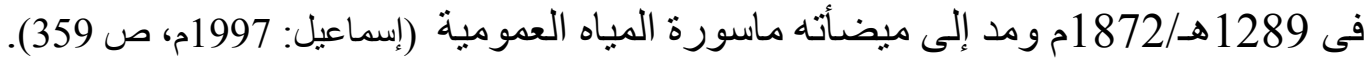

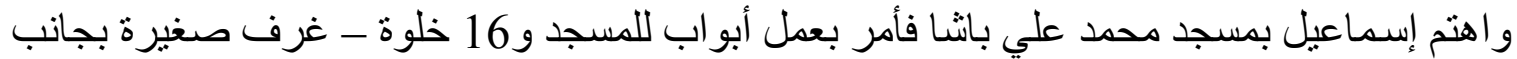

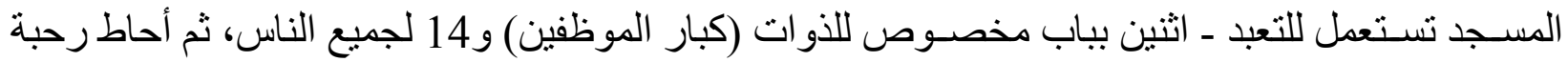
الجامع بسور من الحجر، و أهدى مصحفين شريفين بماء الذهب، وظل وقف إسماعيل الكبير على المساجد -

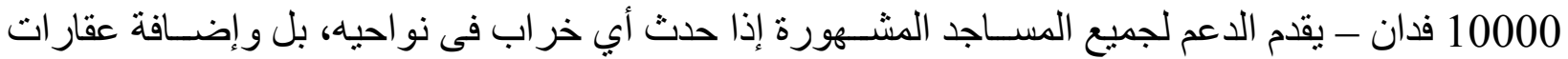

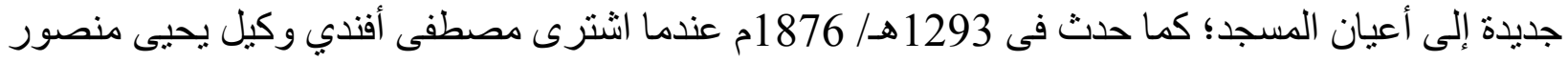

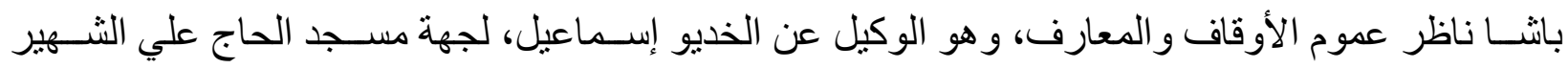

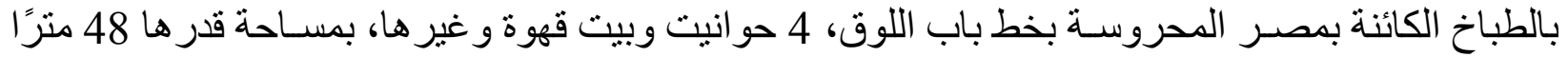

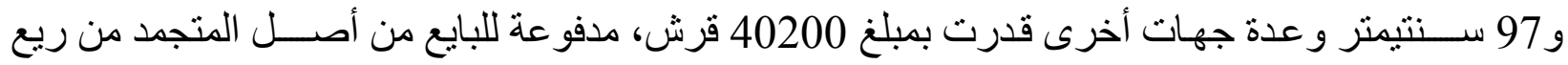

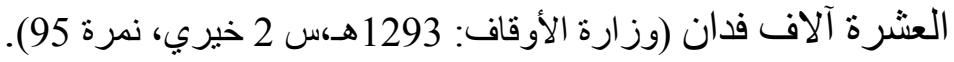

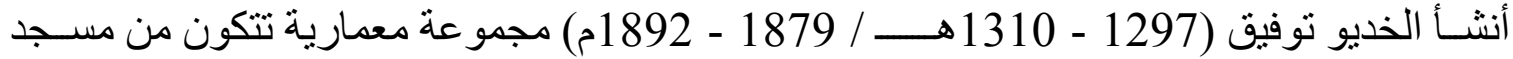

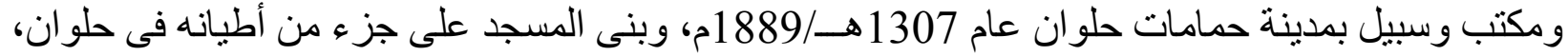

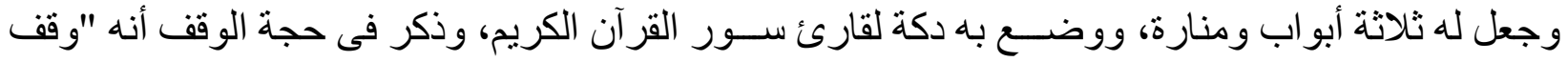

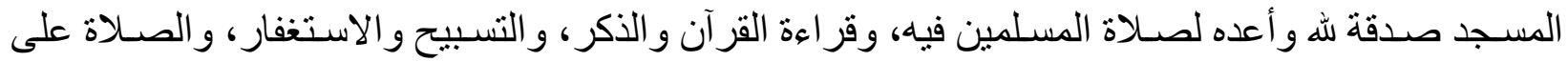

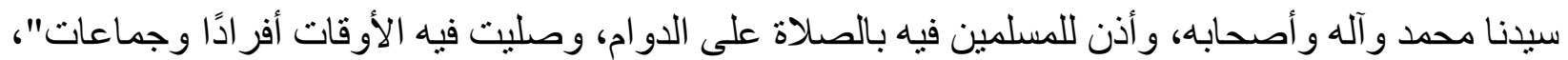

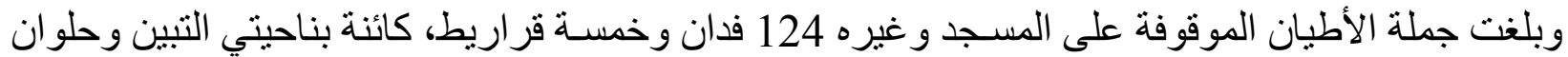

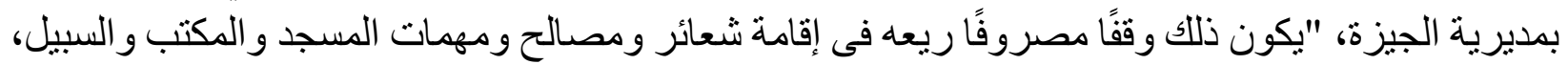

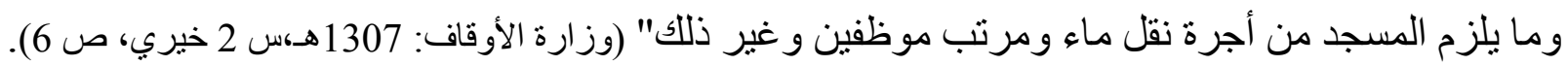

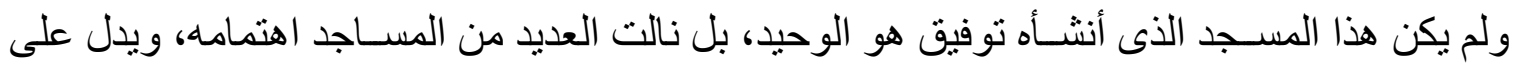

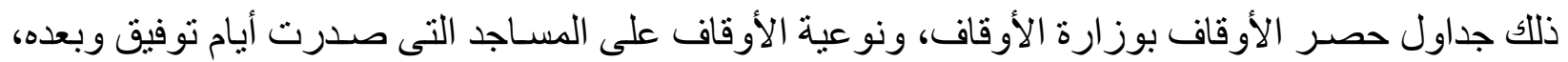

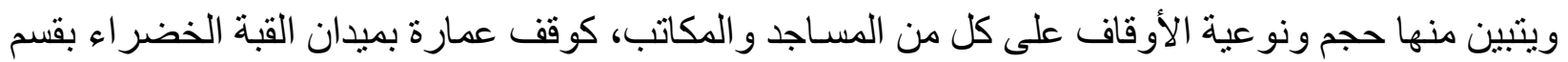


الموسكي بمدينة القاهرة، مسـاحتها 1425م²، وأخرى 1419م²، وثالثة 1293م²، ور ابعة 1285م² و غير ها،

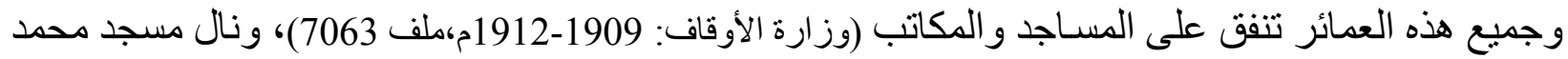

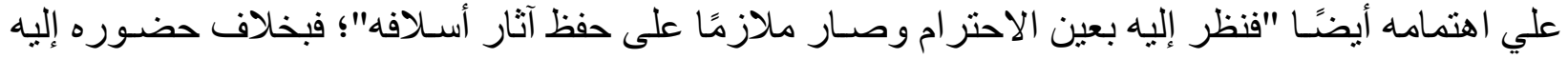

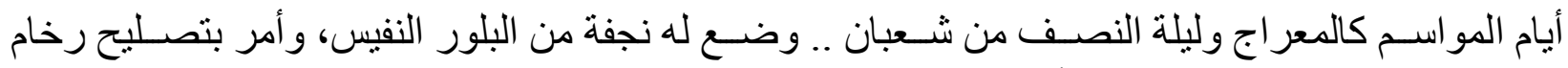

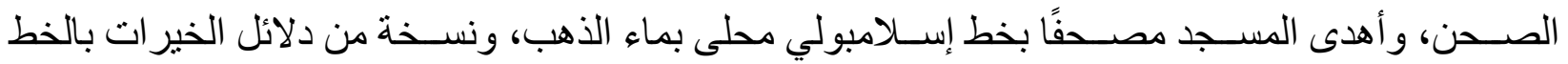

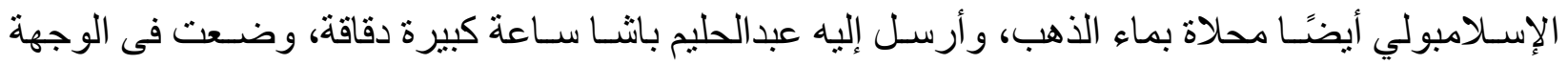

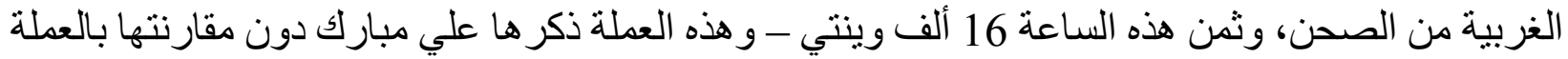

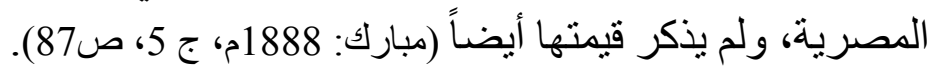

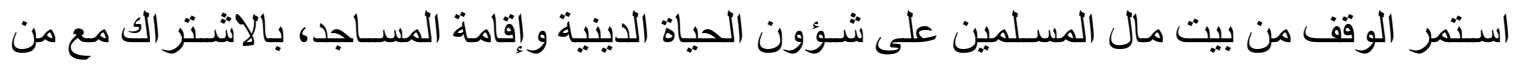

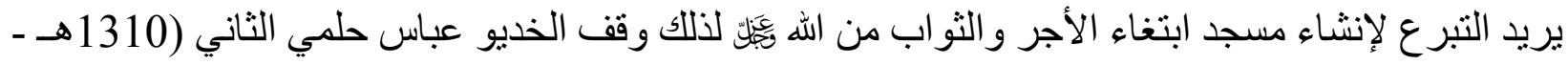

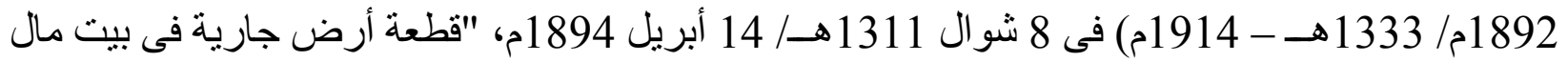

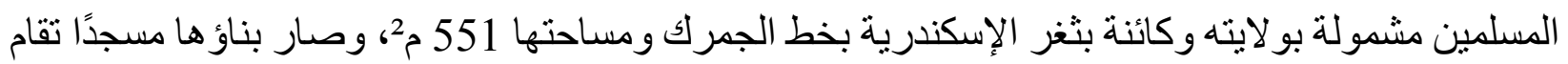

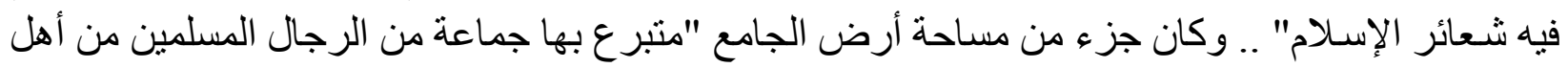

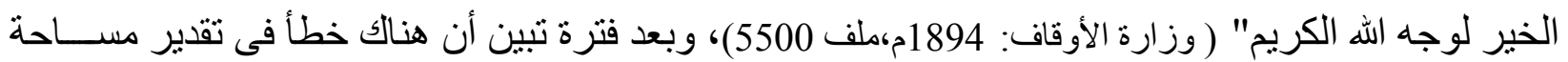

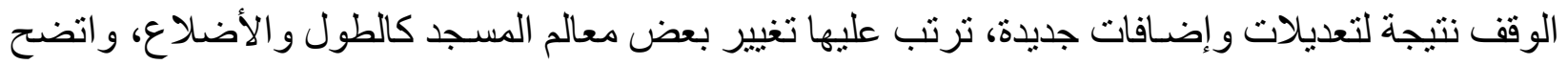

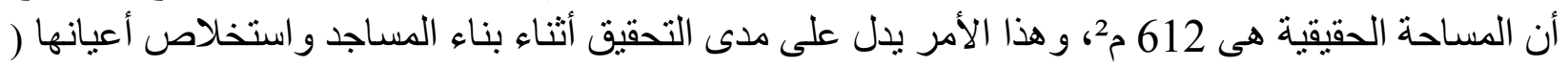

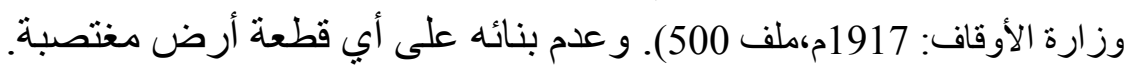

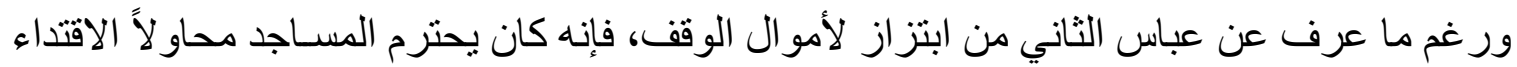

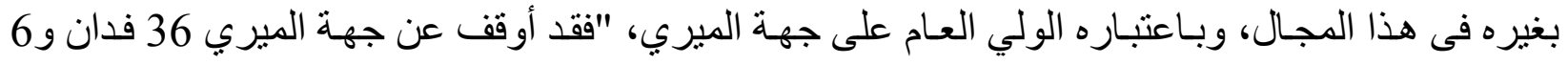

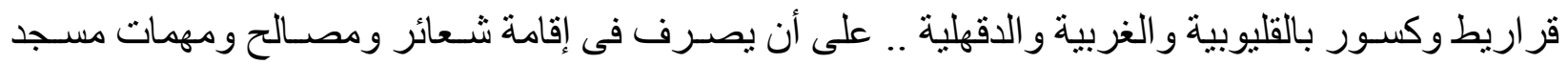

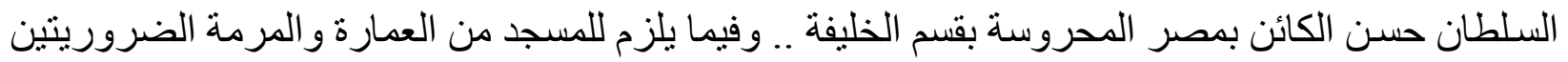

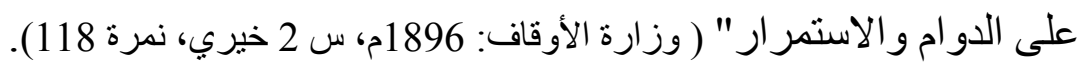

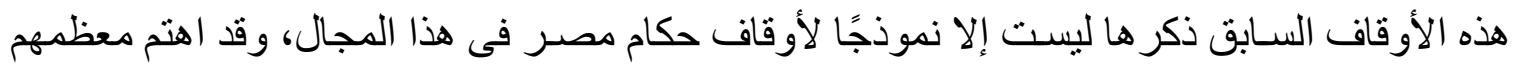

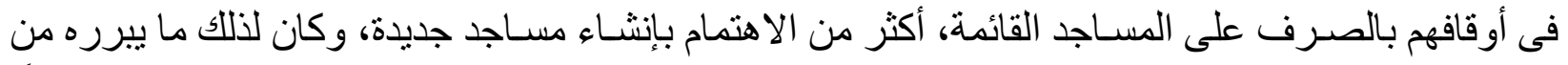

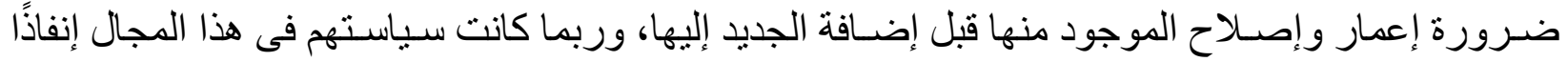

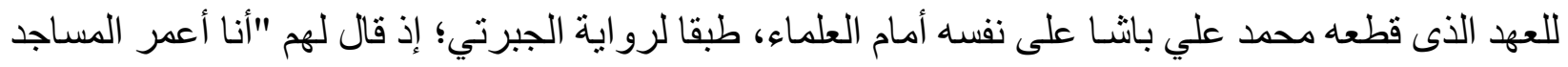

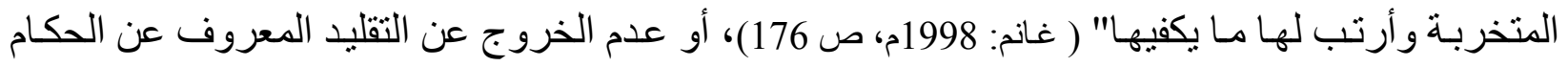

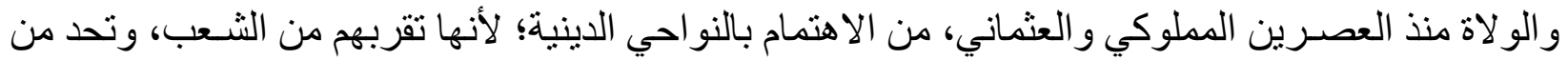
مظالمهم. 2-أعضاء السلطة الحاكمة والأوقاف على المساجد: 


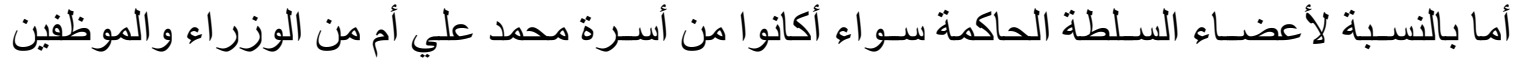

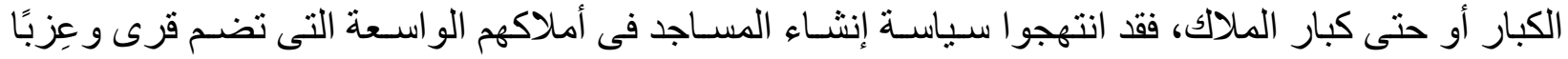

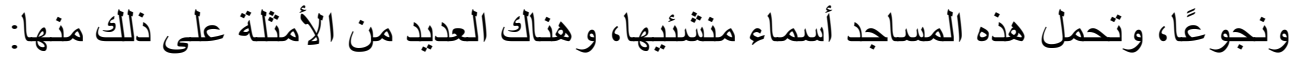

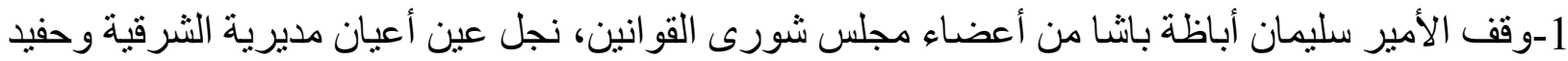

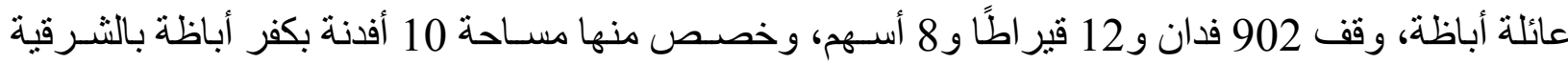
على المسجد الذى أنثـأه، يصرفها فى عمارة وترميم و إقامة شـعائر المسجد (وزارة الأوقاف: 1895مكس 1 قديم،

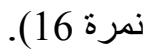

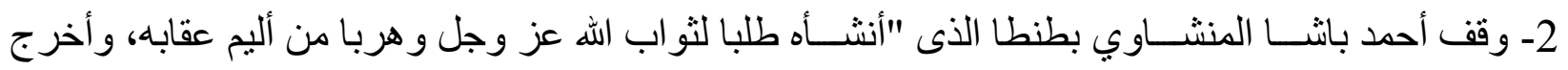

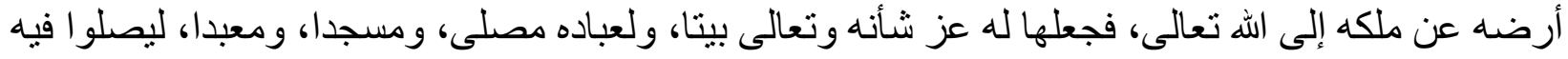

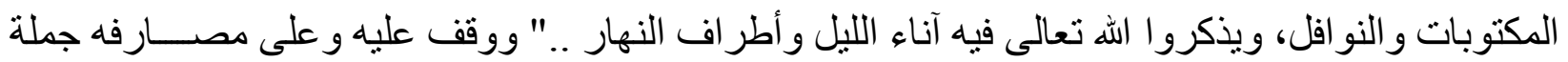

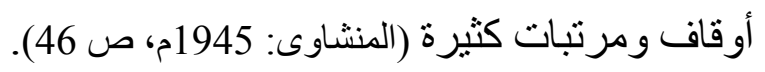

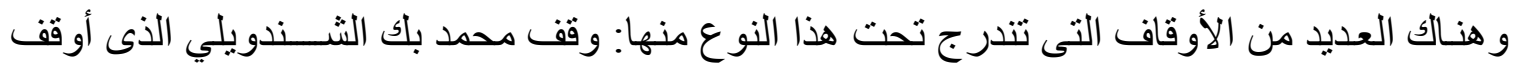

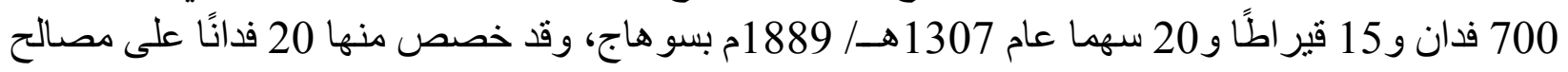

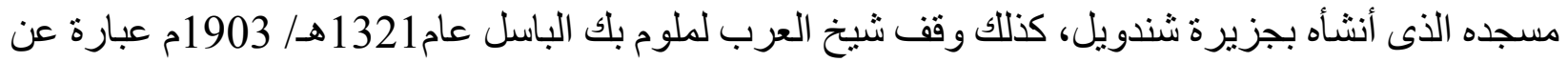

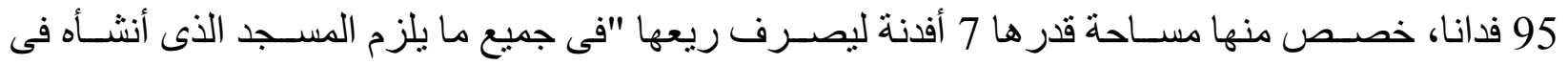

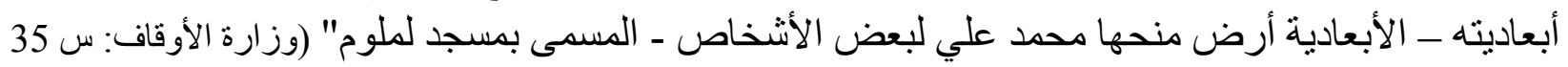

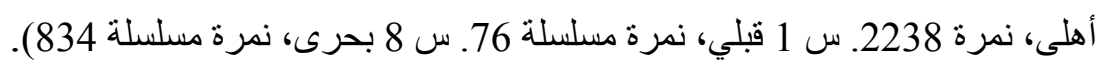

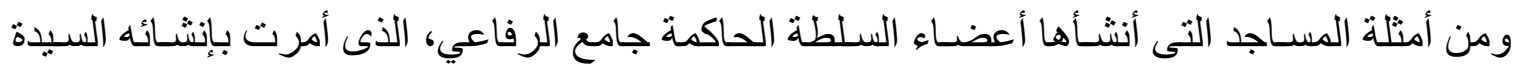

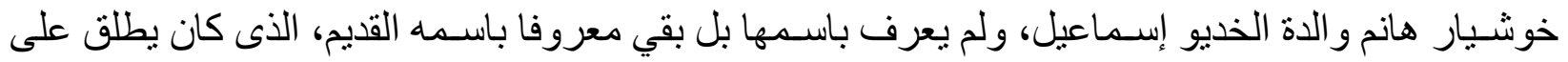

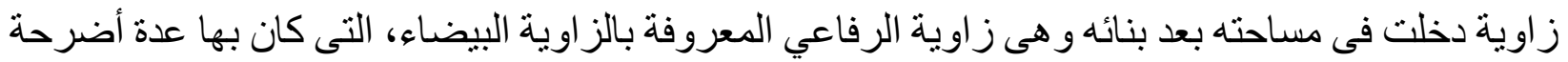

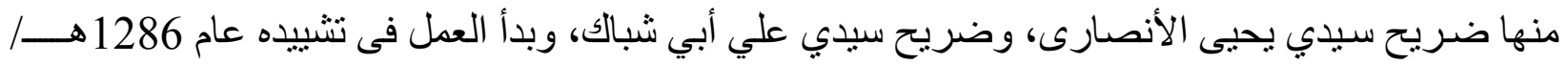

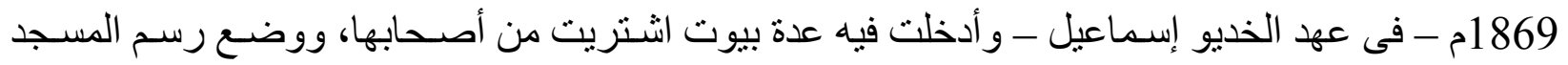

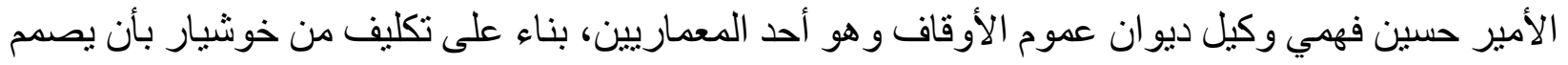

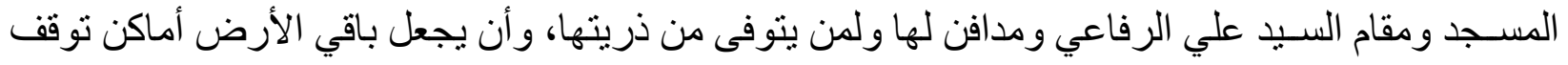

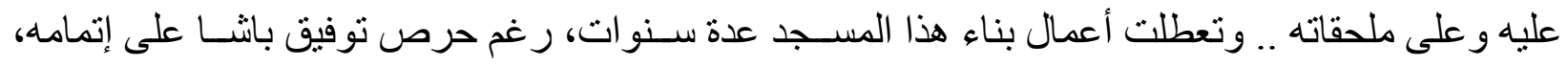

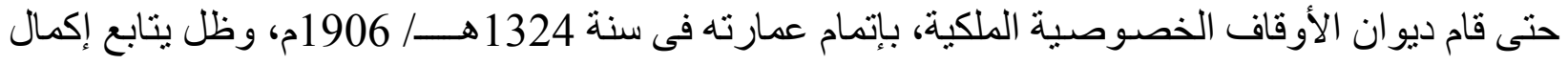

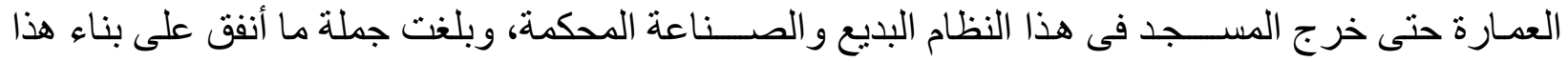

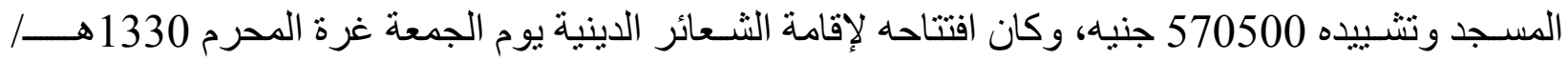

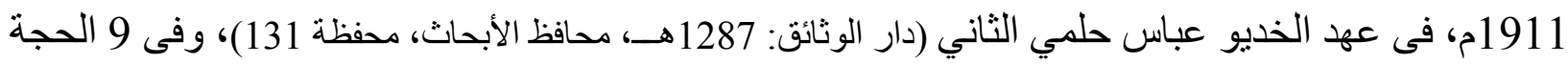

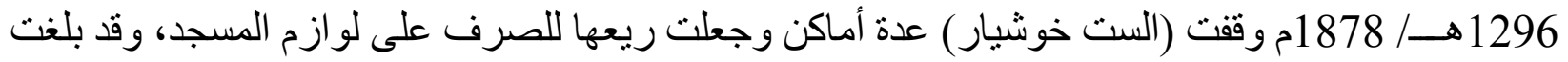
جملة ما رتبته لموظفى المسجد 3080 قرشًا شهريا، هذا خلاف المرتب للمكتب الذى أنشأته ومدفنها و المو اسم 
و المو الد (مبارك: 1888م، ج 4، ص ف 114-114)، وهذا المسـجد هو أعظم ماشـيب من المباني فى مجال العبادات

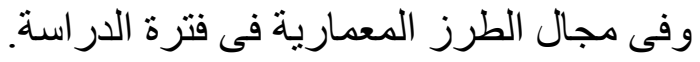

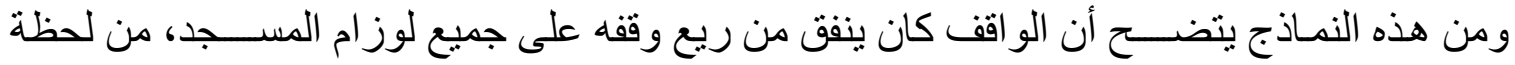

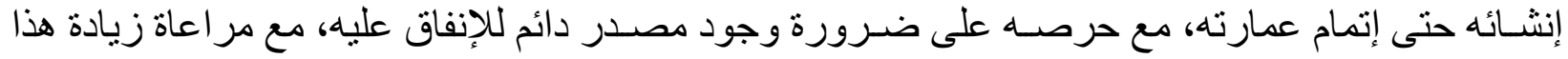
المصدر فى المستقبل بشر اء أعيان جديدة تضاف إلى أعيان الوقف. وتحفل وقفيات هذه المساجد بكل تفاصيل

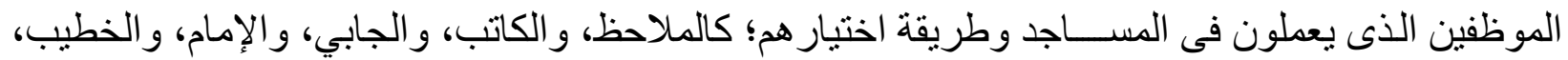

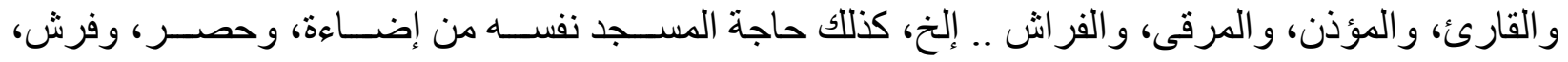

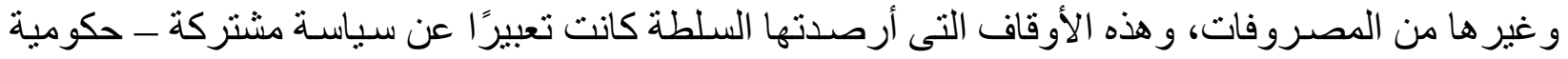
أهليـة - بين الدولة والأهـالي للنهوض بـالمجـال الديني، وقد تشـــابهت أوقاف كبار الملاكت مع أوقاف الحكام و الأمر اء أو الموظفين الكبار، فى إنشـاء المسـاجد والوقف عليها ومتابعتها لتأكيد استمر ار أداء الثعائر الدينية

\section{2-أوقاف الأهالي على إنشاء المساجد والوقف على الموجود منها:}

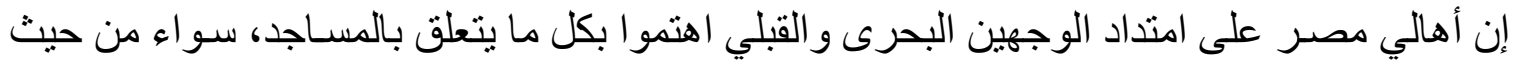
الوقف عليها و على مصــالحها، أو من حيث إنشــاء مســاجد جديدة والوقف عليها وتوفير أوجه نفقاتها (وزارة

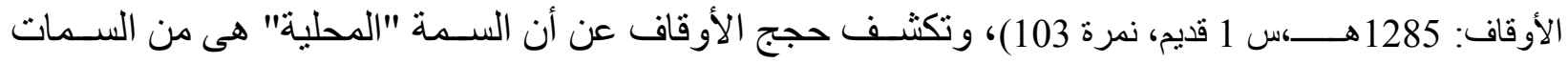

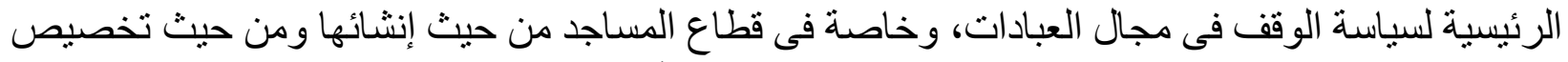

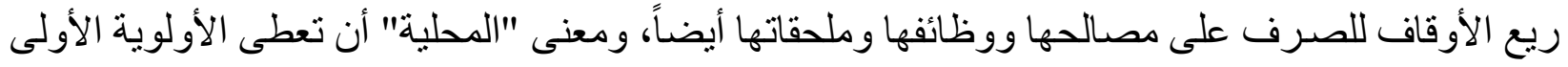

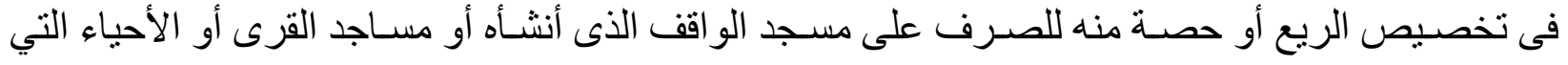
ينتمي إلبها أو المقيم بها (غانم: 1998م، ص 186)، ويتضــح ذلك من خلال وثائق وحجج الوقف على المســاجد التى نشأت طيلة القرن التاسع عشر. أولاًِ الوقف على إنشاء مساجد والإنفاق علئها:

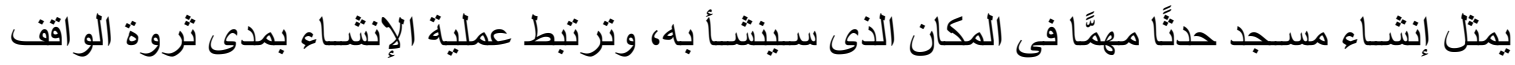
وحجم الأعيان التى سيرصدها عليه؛ فإذا كان الو اقف من ذوي الأملاك فسيكون المسـد أكثر اتساعًا، ويبدو

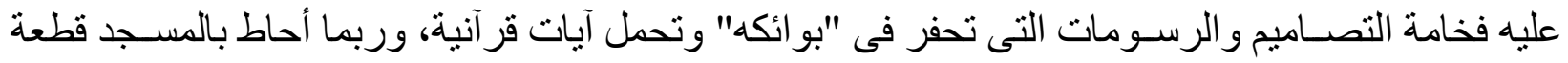

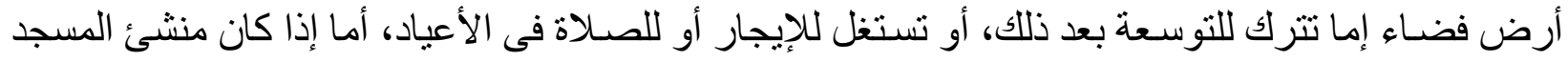

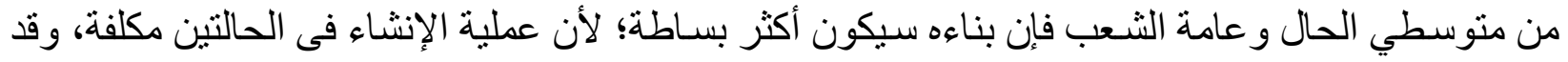

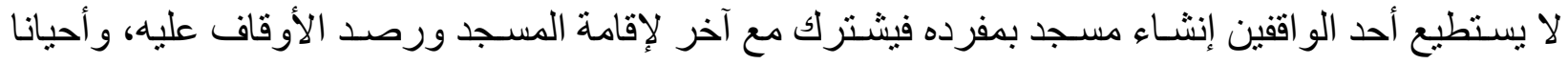

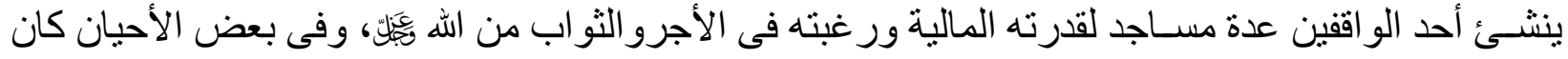
الو اقف يخصص الريع كله للمسجد أو بعضه لينفق منه على لو ازمه الهـ 
ففي عام 1285 هـ/ 1868م أوقف متولي أفندي بن منولي المعاون بمخزن الفحم بيتين وقهوة ومفازة

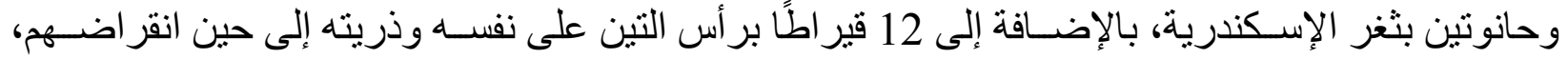
يصـرف على مصــالح المســد المعروف بإنثـاء الواقف بالثخر، لإقامة شـعائره الإسـلامية (وزارة الأوقاف:

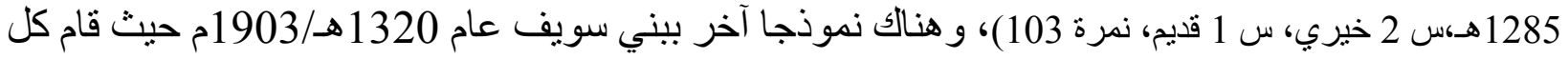

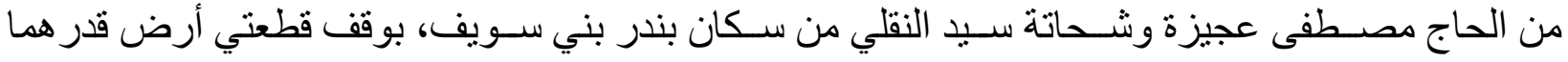

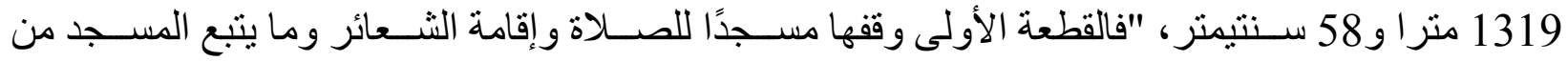

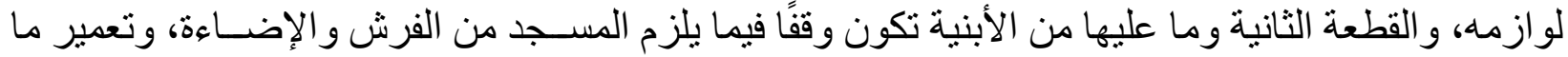

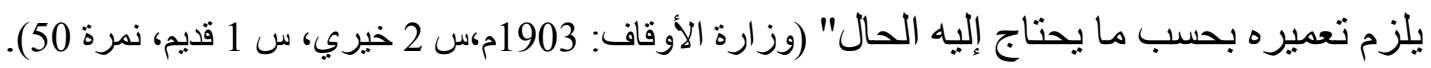

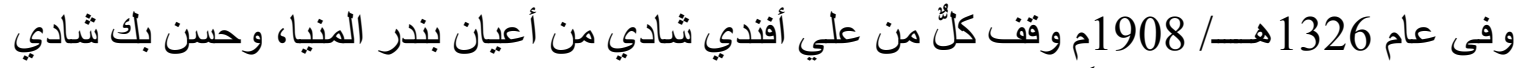

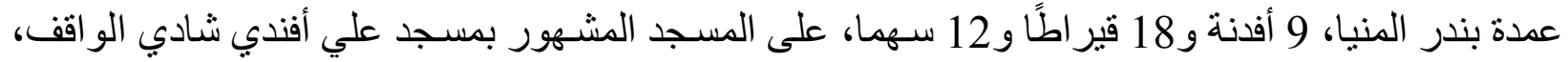
"يصـرف ريع جميع الوقف فى إقامة شــعائر ومهمات ومصــالح المســد المذكور وخدمته" (وزارة الأوقاف:

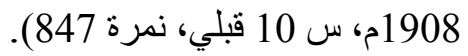

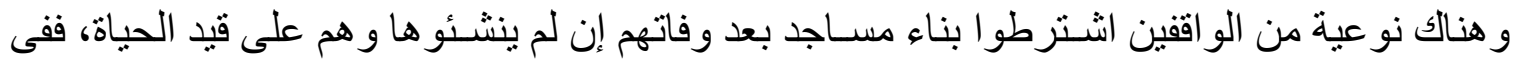

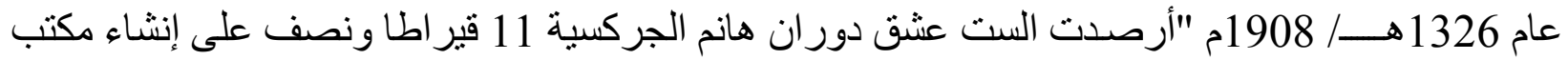

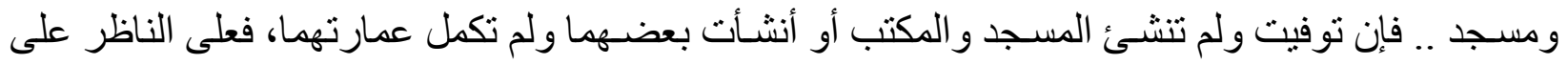

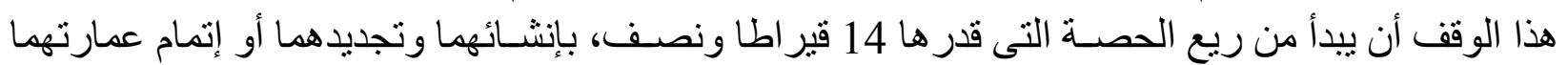
حتى يكونا صـالحين" (وزارة الأوقاف: 1908م، س 11 قبلي، نمرة مسلسلة 1159)، و وإن كانت هذه الو اقفة قد أقرت

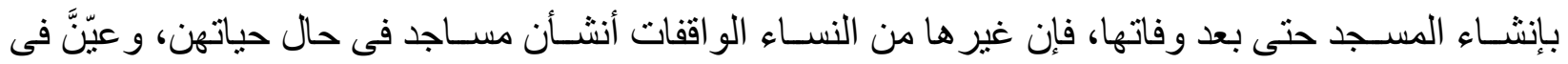

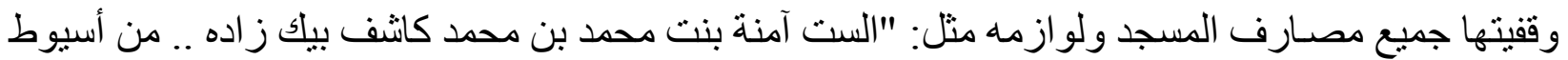

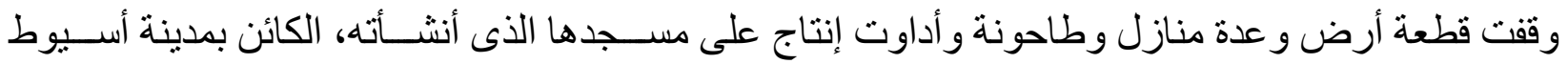
بوسطها بالقرب من السادة الأنصار " (وزارة الأوقاف: 1878م، س 1 قديم، نمرة مسلسلة 92).

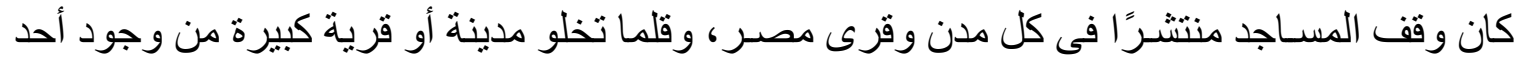

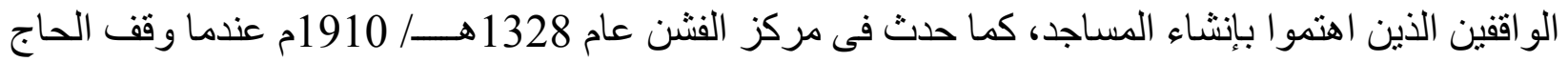

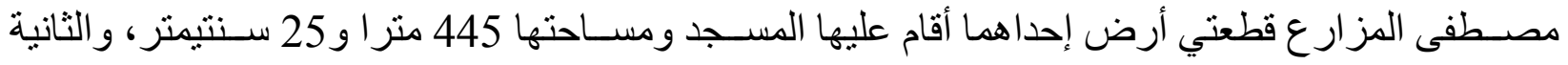

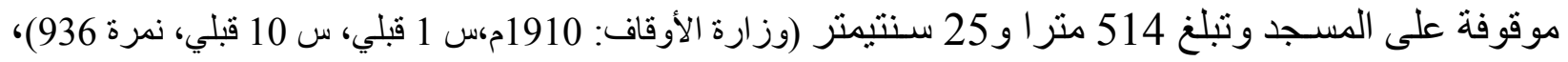

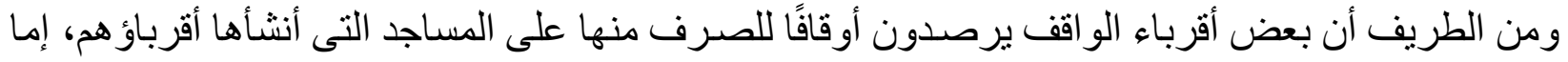

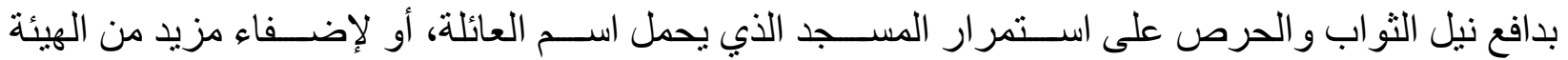
الاجتماعية على أنفسهم (وزارة الأوقاف: 1903م، س 1 قبلي، نمرة مسلسلة 99).

ثانياً_ الوقف على أقرب مسجد للواقف - فى حال تعذر الصرف على مسجده:

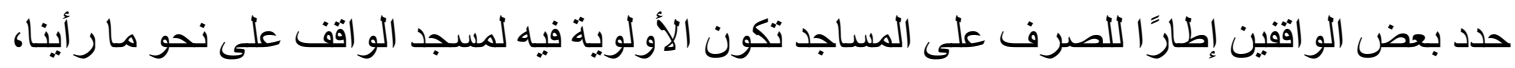

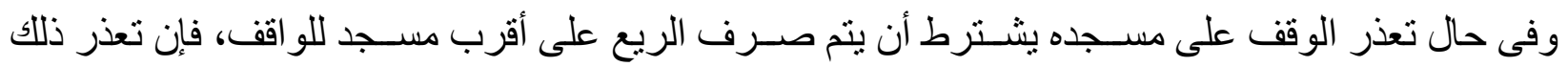


أيضـا يكون الوقف على "الفقر اءو والمساكين أينما كانو ا وحيثما وجدوا" (وزارة الأوقاف: حجة 2281)، ومن ذلك

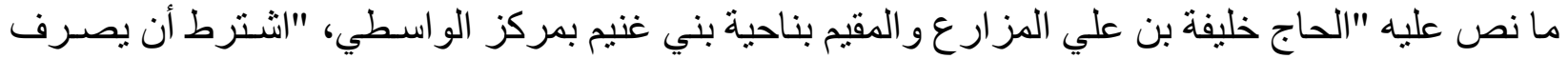

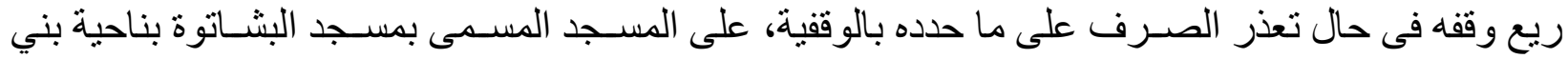

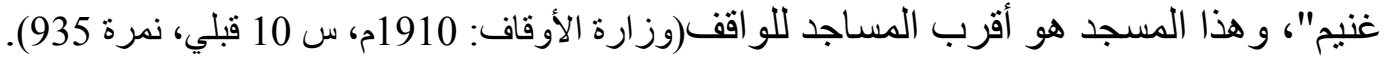
و إذا كان من طبيعة النساء الميل إلى جنسهن فإن ذلك انعكس على طبيعة أوقافهن؛ ففى عام 1327 هـ/

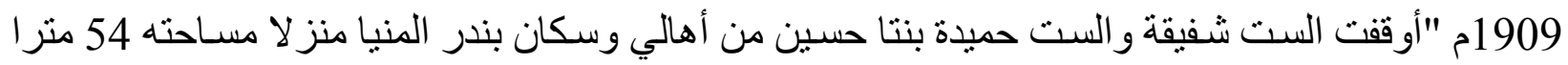

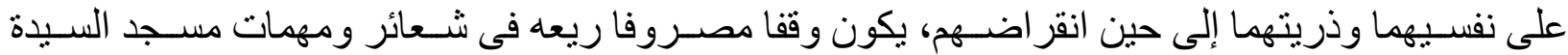

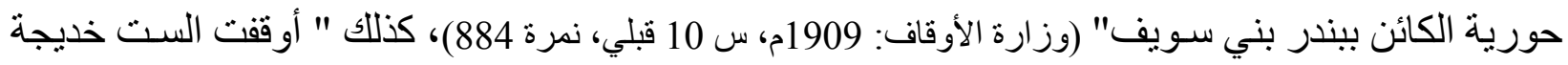

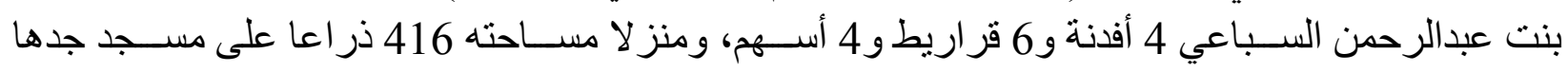
المعروف بمسـجد السـباعي، الكائن بمحل سكنها بناحية بني عدي القبلية" (وزارة الأوقاف: 1909م، س 10 قبلي، نمرة 890). وقد أوقف رزق حسن الفر اش أحد سكان قسم الخليفة بمصر ، قطعة أرض تصرف "فى إقامة شعائر ومصسالح مهمات مسـدى ومقامي وضريحي سيدي محمد الأنور و السيدة فاطمة شجرة الدر .. الو اقعين بقسم

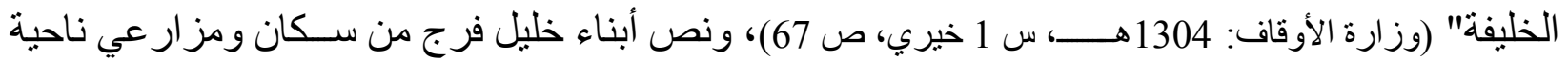

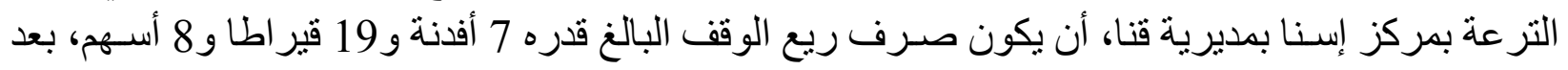

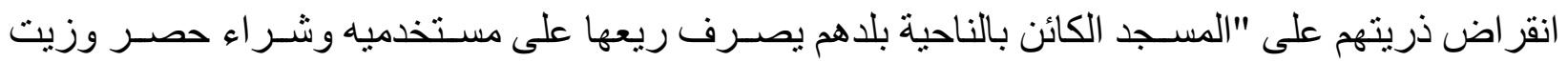
وبناء ونرميم" (وزارة الأوقاف: 1910م، س 10 قبلي، نمرة مسلسلة 927).

ثالثاـ الوقف على مسجد معين أو أكثر حدده الواقف بعد انقراض الأرية: حرص كثثير من الو اقفين على تعبين مســاجد بالاســـ لينفق من ريع وقفه بعد انقر اض الذربة علية عليها،

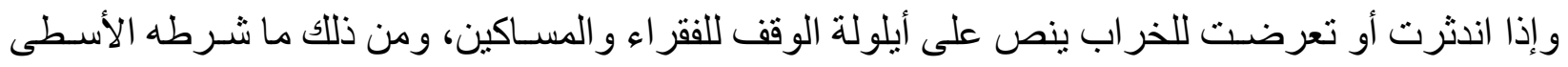

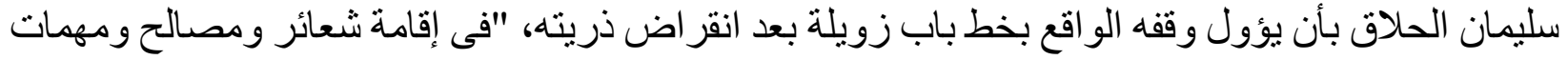

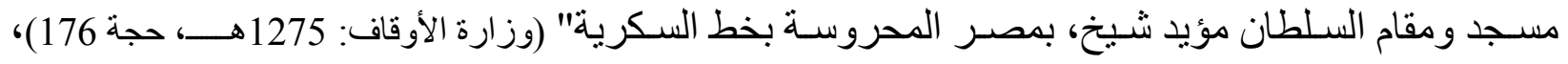

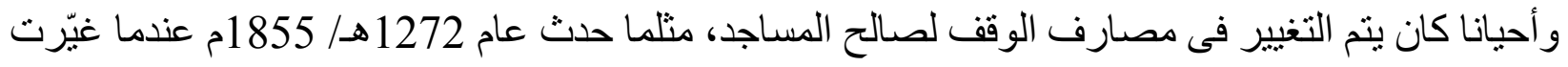
السيدة ممتاز قادن فى شـروط وقفها "وجعلت ريع 50 فدانا، يصـرف على مسـجد القاضـي عبدالغني الفخري

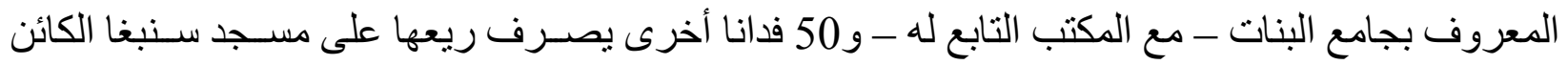

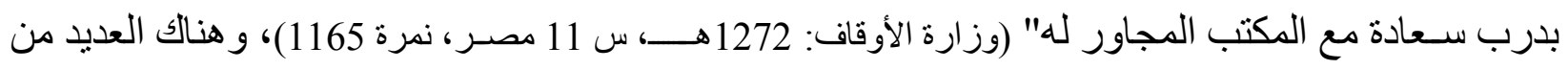

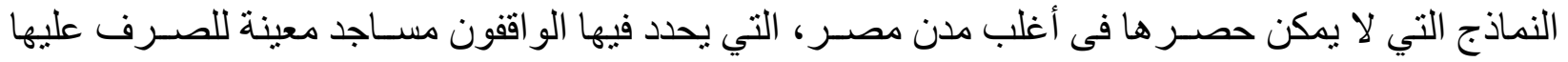

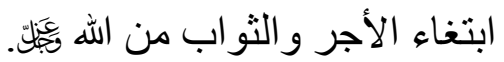




\section{رابعا- الوقف على مساجد القرية أو البندر أو المدينة:}

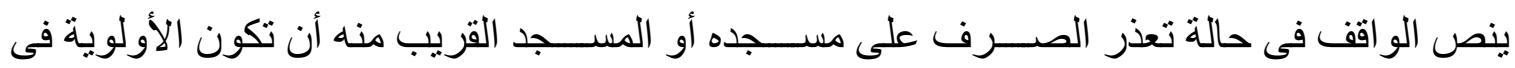

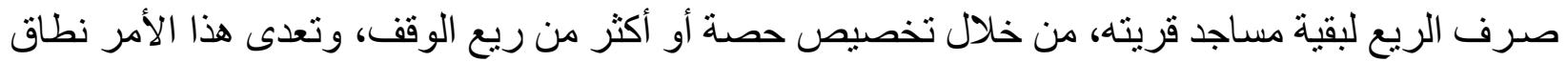

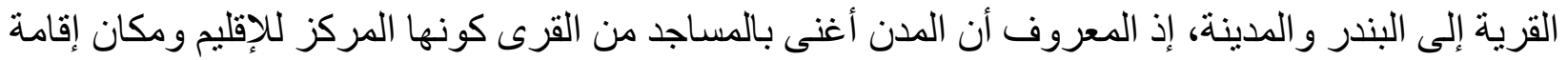

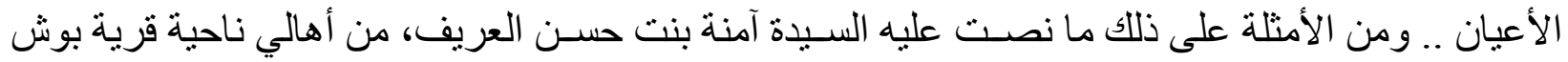

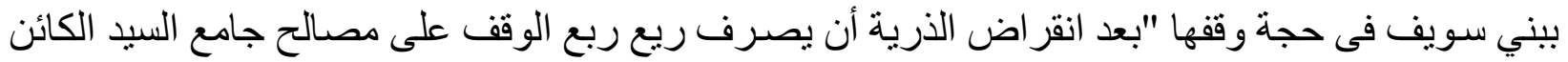

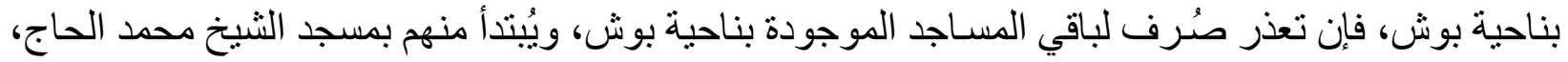

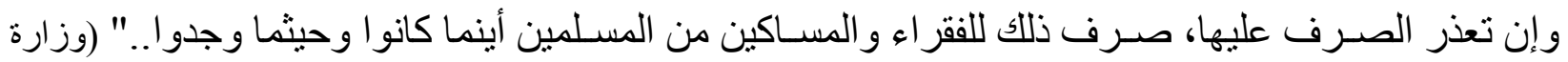

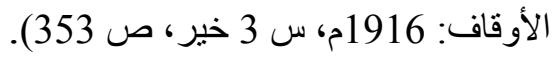
ومن الأوقاف التى خصـصـت لمســاجد المدن ما شـرطته السـيدة أسـما هانم فى حجتها الصــادرة من

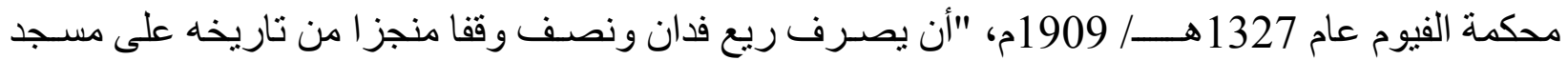

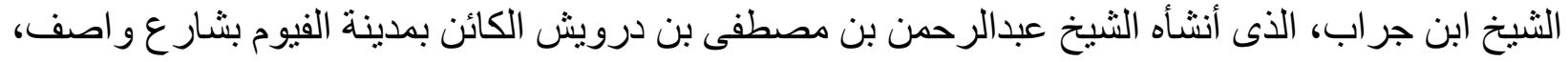

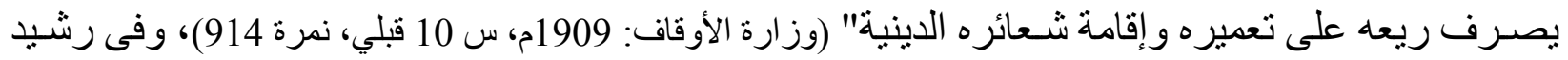

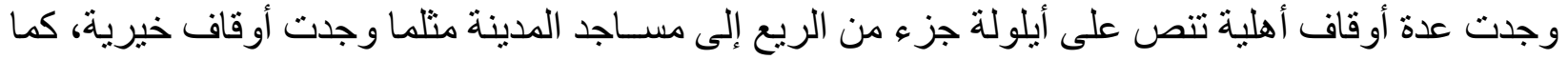

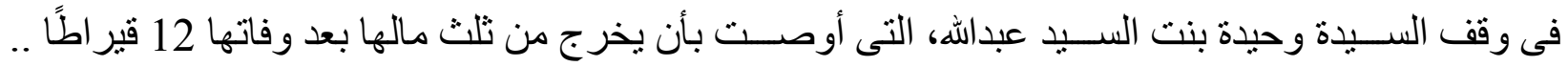

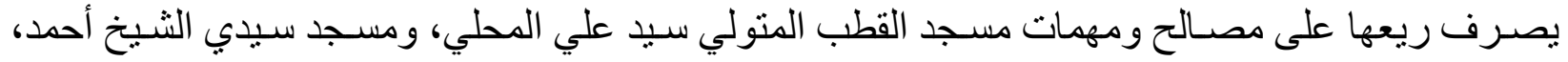

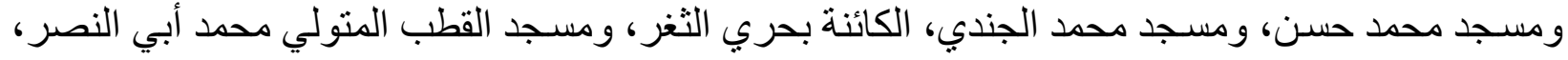

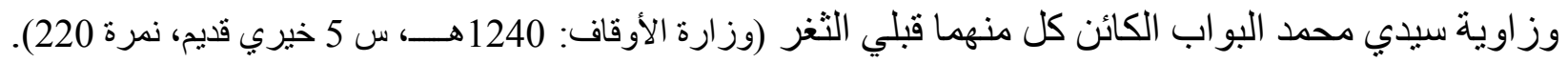

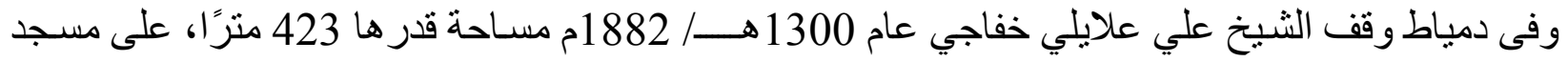

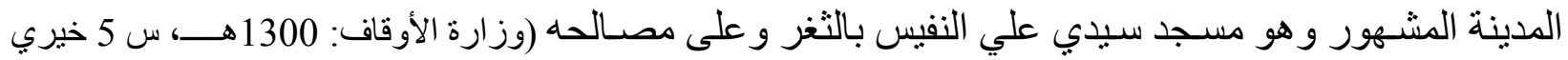

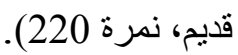

وكانت أوضح الأمثلة للإنفاق على مساجد المدينة بالكامل ما وقفه السيد الثريف الثيخ محمد محمود

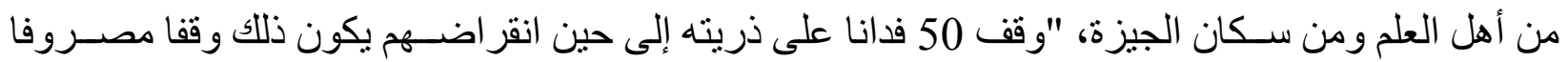

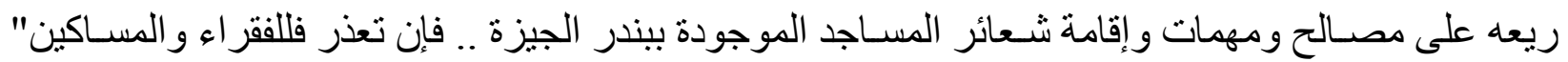

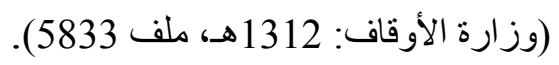

\section{خامساـ الوقف على مساجد مصر كلها:}

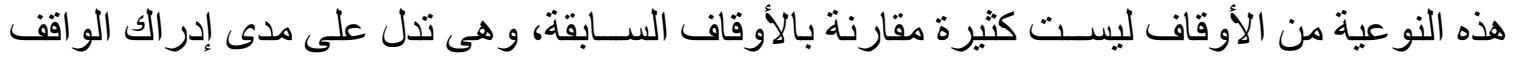

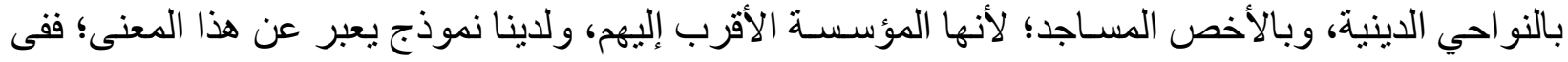

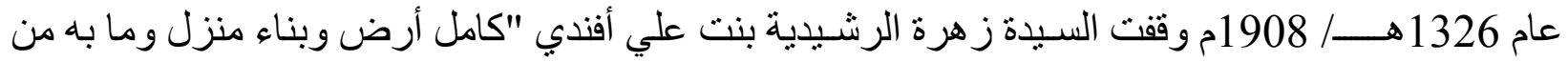

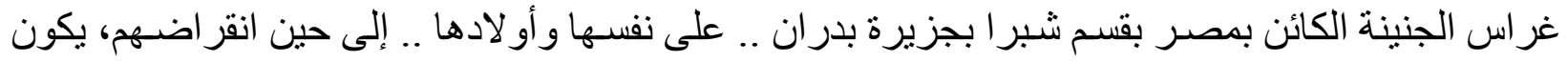


ذللك وقفا مصروفا ريعه فى مصالح ولوازم المكاتب و المساجد الكائنة بمصر المحروسة، التابعة لديوان عموم الأوقاف المصـرية، يقدم منها الأهم فى الاحتياج حسـبما ير اه الناظر على ذلك، فإن تعذر فللفقراء و المسـاكين

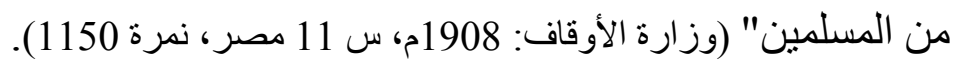

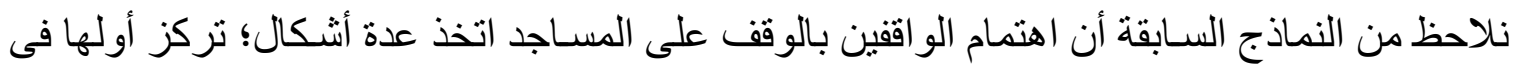

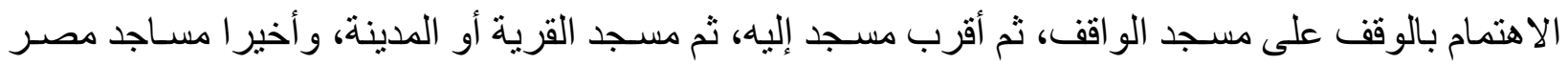
كلها، وبالتالى يبدأ تركيز الو اقف على السمة المحلية، ثم يتسـع الوقف ليشمل المدن وكافة أقاليم مصر - ويعبر

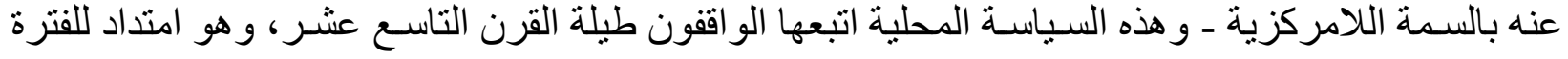

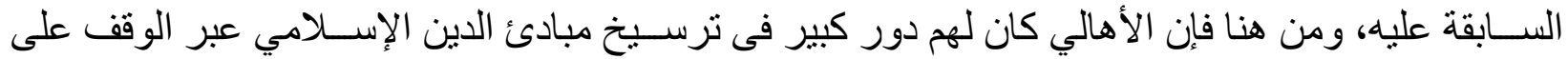

\section{4-الوقف على مساجد آل البيت:}

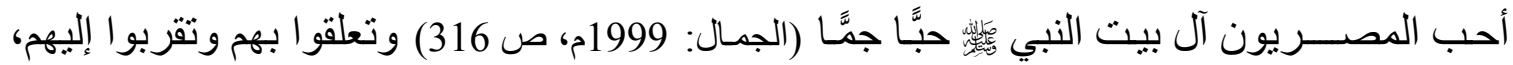
و انعكس هذا الحب على مسيرة الوقف، فعدد كثير من الو اقفين إلى تخصيص ريع الوقف بالكامل أو جزء منه أو يجعل أيلولة وقفه على أحد مساجد آل البيت وهى: مسجد الإمام الحسين، والسيدة زينب، و السيدة رقية أبناء

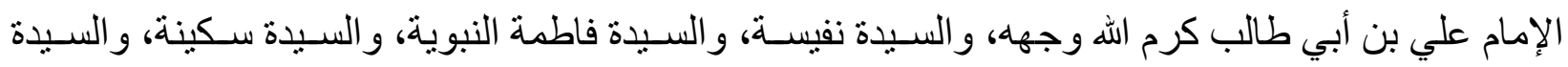

عائشة النبوية. كان أكثر مسـاجد آل البيت شـهرة فى مجال الوقف مسـجد سـيدنا الإمام الحسـين، وهو يقع فى ثُّن الجمالية بالقاهرة المعزية قرب الجامع الأز هر وخان الخليلي، أنشأه الفاطميون سنة 549هــ/ 154مة 1154م على يد

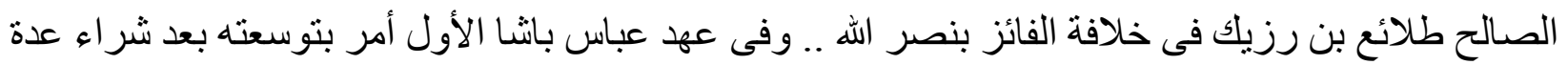

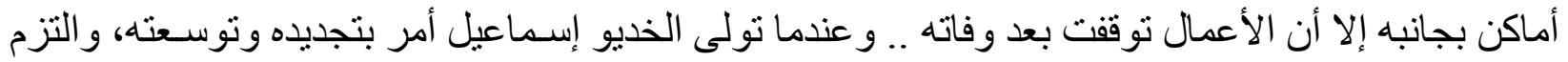

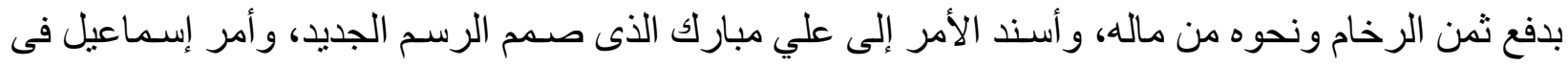

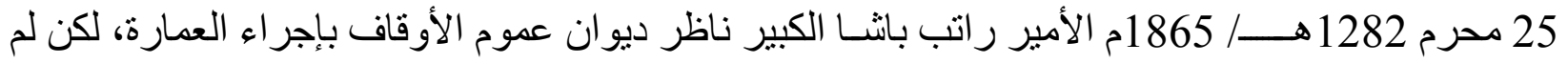

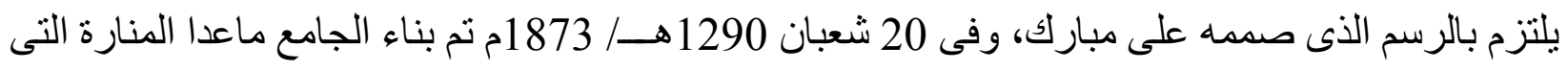

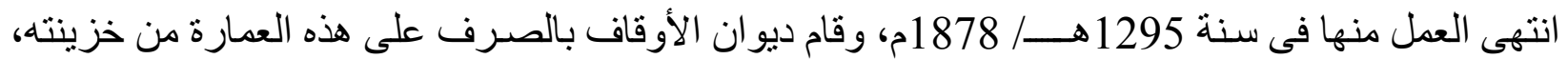
فبلغت جملة المصاريف 7860152 قرشاو 21 نصفا فضة، غير ما تبرع بـه الخديو إسماعيل من خزينة ماله

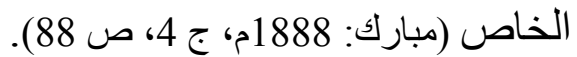
تنو عت الأوقاف على مســد الحسـين ما بين أوقاف مباثــرة أو مشــتركة أو تؤول إلبه، ومن كثرة

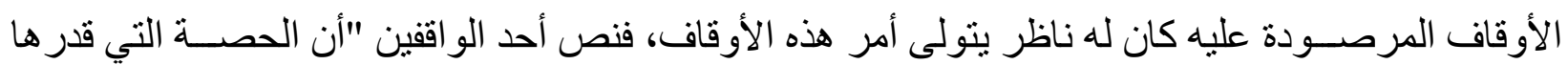

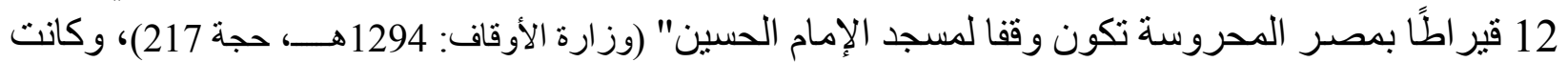

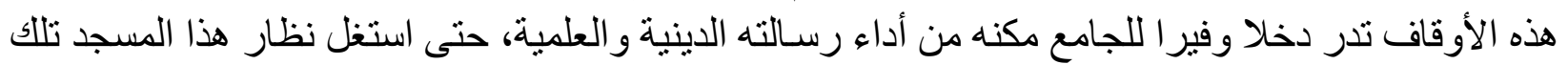

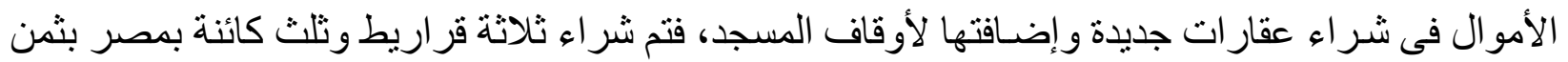
قدره 5386 قرشا و6 أنصاف فضة (وزارة الأوقاف: 1312 هـ، س 2 خيري، نمرة مسلسلة 57)، وفى عام 1288 هـ/ 
1871م تم شــر اء أنقاض لصـــالح الوقف بمبلغ 175 قرش (وزارة الأوقاف: 1288هـــــ، س 1 خيري، ص 46),

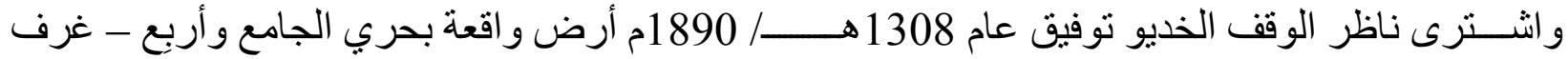

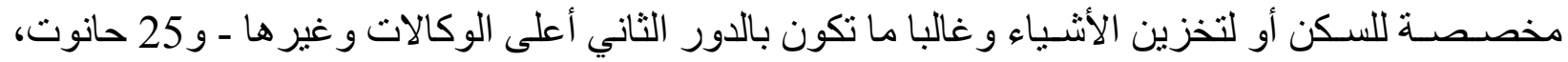
بثمن قدره 132549 قرشا و12 نصف فضة من مال الوقف المتجمد بخزينة الأوقاف (وزارة الأوقاف: 1308هـ،

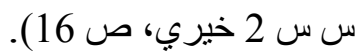

كانت أوقاف المسـد منتشرة فى عدة مدن مصرية، لذللك كانت تخضع للتحقيق إذا دخلت أجز اء منها حيز أر اضـى أخرى، مثلما حدث فى عام 1272هــــ/ 1855م بثـأن التحقيق فى مسـاحة أرض تابعة لوقف

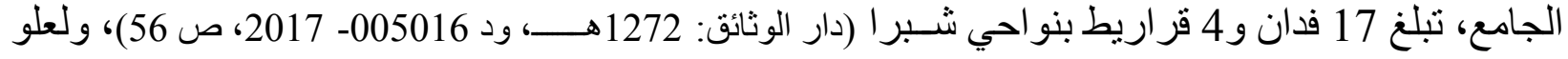
مكانـة هذا الجامع كان يحظى برع عاية الســـلطان العثماني، فقد أرســلـل مجموعة من اللوحات أو اليفط مزينة

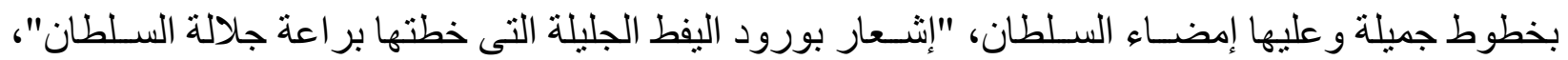

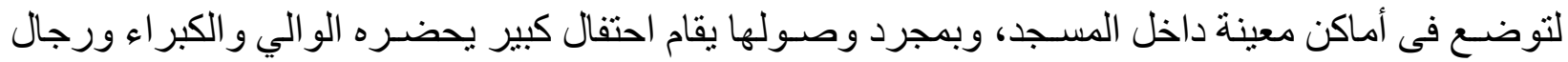

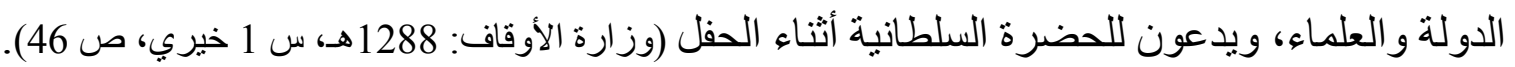

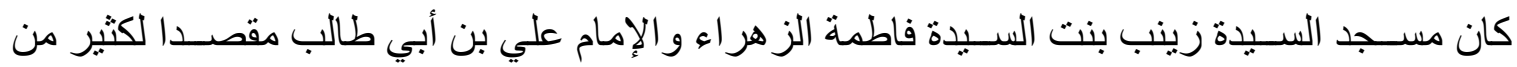

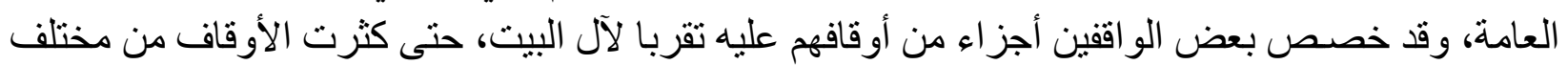
الفئات و الثر ائح الاجتماعية، ففى عام 1268هــــ/ 1851م وقفت "الحرمة فاطمة المدعوة فطومة بنت الحاج حسن البلم، بيت كائن ببو لاق على نفسـها ثم من بعدها يكون وقفا مصروفا على مسجد ومقام السيدة الثريفة،

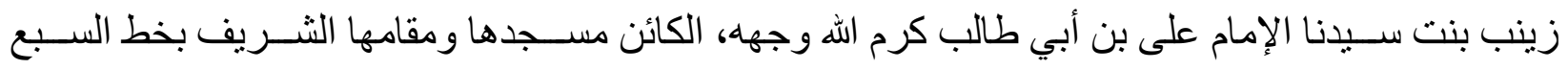

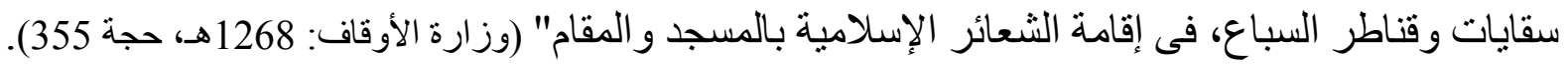

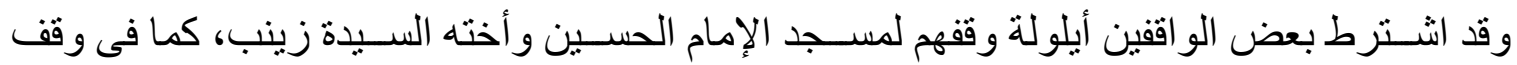

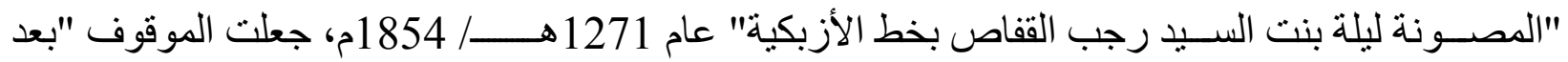

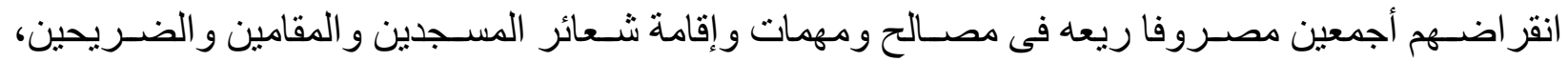
فالنصف 12 قير اطا يكون وقفا على مسـد وضـريح الإمام الحسين .. و النصف الثاني 12 قير اطا يكون وقفا على مسجد ومقام وضريح شقيقته، السيدة الثريفة زينب بنت الإمام علي" (وزارة الأوقاف: 1271 هـ، حجة 353)،

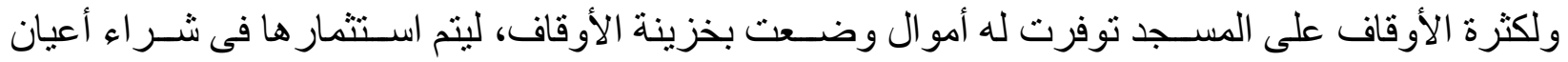

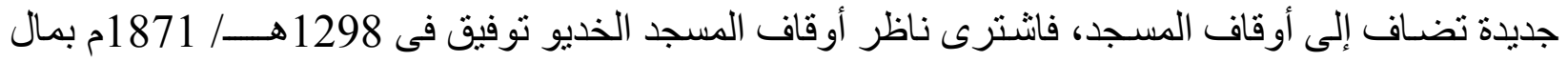
جهة الوقف، حصة قدر ها "8 قراريط وكسور فى بنا المكان الكائن بقسم السيدة زينب بثمن قدره 4394 قرشا و ثلثث" (وزارة الأوقاف: 1300هـــ، س 1 خيري، ص 27)، و هذه المعاملات تدل على الحالة الاقتصـادية الممتازة

اتجه كثير من الو اقفين لرصد أوقافهم على مسـد ومقام وضـريح "السيدة الثـريفة نفيسـة بنت سيدي حسن الأنور"، الكائن مسجدها بمصر المحروسة بقسم الخليفة بجهة باب القر افة الصغرى، ففي عام 1282 هـ/ 1865م وقف إسـاعيل صديق مفتش عموم الأقاليم البحرية، أبعادية بناحية دمياط بمدينة الغربية قدر ها 553 
فدانا، على نفسـه وذريته "إلى حين انقر اضـهم يكون وقفا يصرف ريعه على مصالح ومهمات وخير ات مسجد

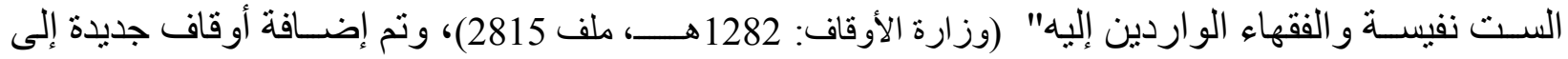

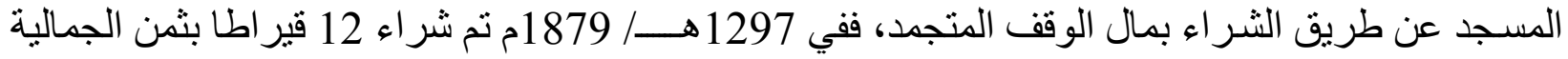

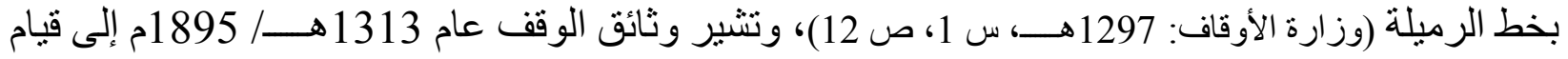

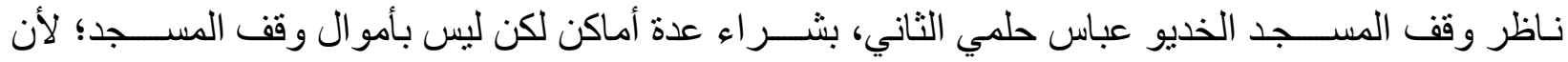

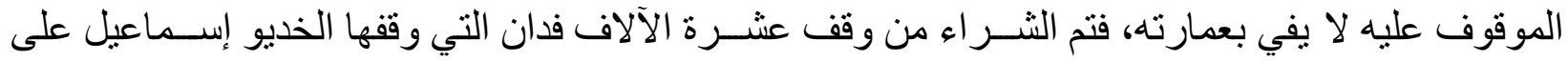
المسـاجد المشـهورة و غير ها، فتطابق شـروط وقفه مع حالة المسـد، وكانت قيمة ما اشـتر اه حصـة قدر ها 17 قير اطا ونصـف، "فى كامل أرض بناء منزل بقسـم الخليفة ومسـطح منزل مسـاحته 164 منر ا بثمن قدره 92

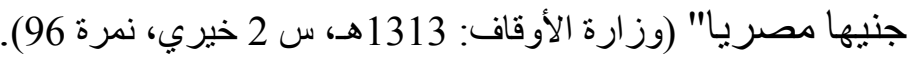

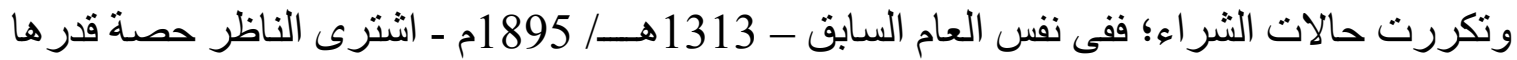
6 قر اريط، "فى كامل أرض وبناء المنزل الكائن بقــــم الخليفة لجهة الوقف"، بثمن قدره 24 جنيها ذهبًا من

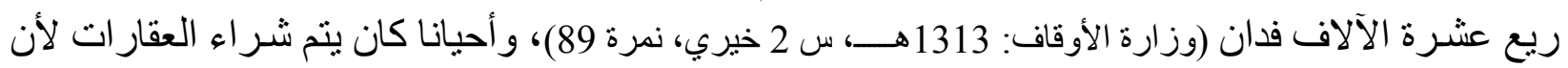

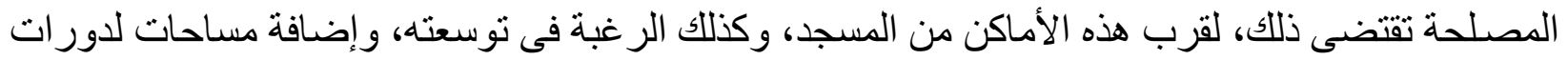

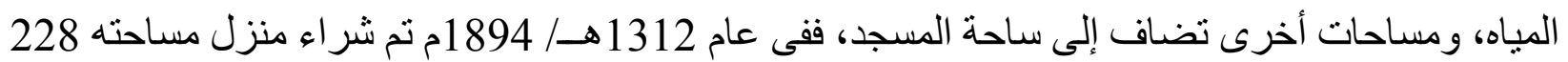
منر او منزل آخر مسـاحته 352 منر ا من ريع وقف عثرة الآلاف فدان أضيفت لوقف المسجد (وزارة الأوقاف: 1312 هـ، س 2 خيري، نمرة 82). وقد خصــص بعض الو اقفين أيلولة وقفه إلى بعض مسـاجد آل البيت، مع تفضـيل مسـجد على آخر ،

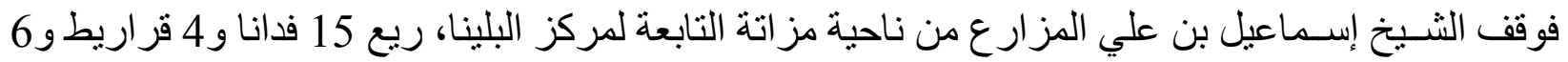
أسـهم "على نفسـه وذريته، وجعل أيلولة الوقف نصـفين: الأول على الحرمين، و الثاني يصـرف فئ على مسـاجد

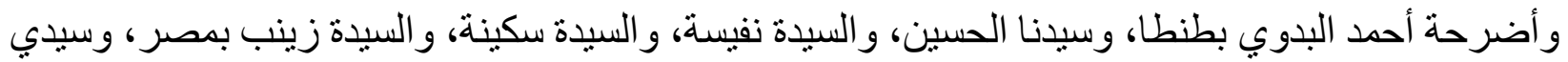

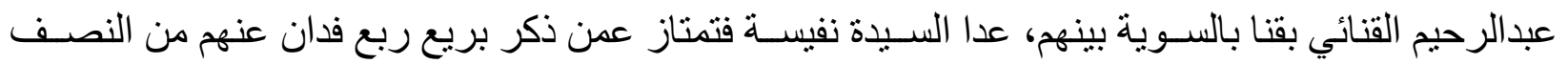

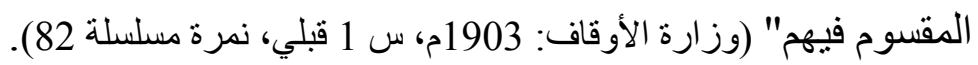

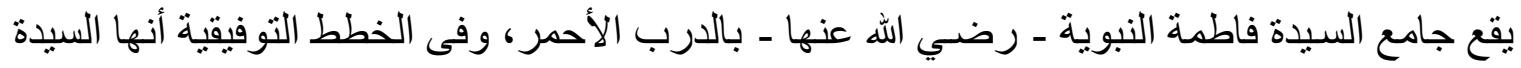
فاطمة النبوية بنت سـيدنا الإمام الحسـين رضـي الله عنهما، وورد في بعض الوثائق أن الأمير سـليمان أفندي

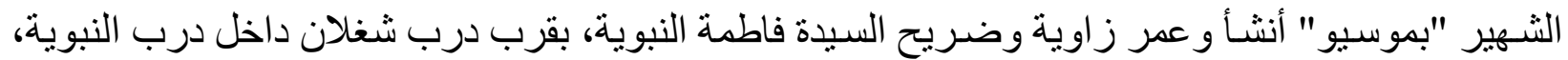

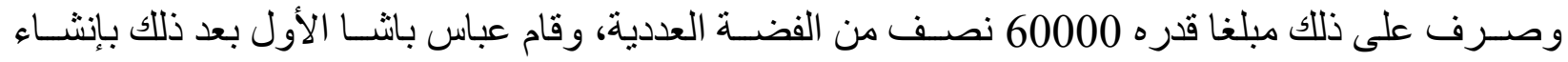

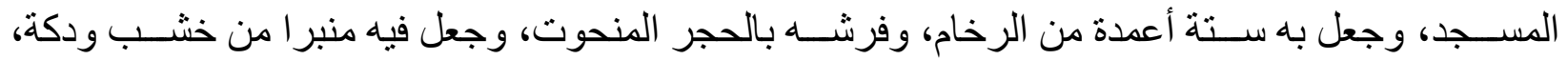

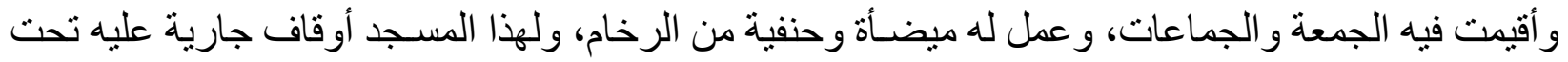
نظر ديو ان الأوقاف، وقال العلامة الأجهورى: هذا المســـد جليل ومقامه عظيم و عليه من المهابة و الجلالة

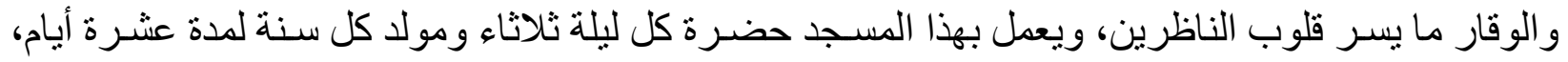
ولها زيار ات كثيرة ونذور (مبارك: 1888م، ج 5، ص 66-67)، وأنثـئ على مسجدها ومقامها أوقاف كثيرة. 
وبخط الخليفة عن شـمال الذاهب من الصـليبة إلى القر افة الصـخرى يوجد جامع السيدة سـينة، وذكر علي مبارك نسبها وذكر الخلاف فيه بأن: سكينة أخت الحسين والمعروف أن سكينة بنته لا أخته، وليس هذا

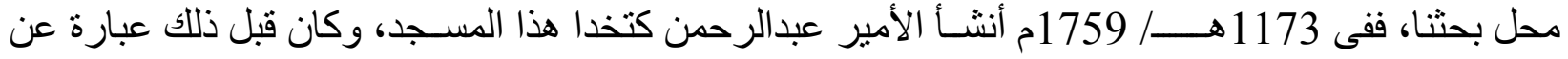

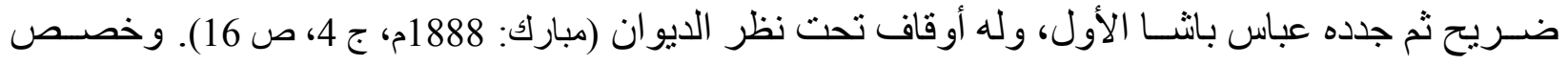

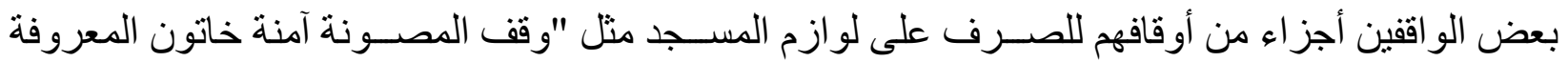

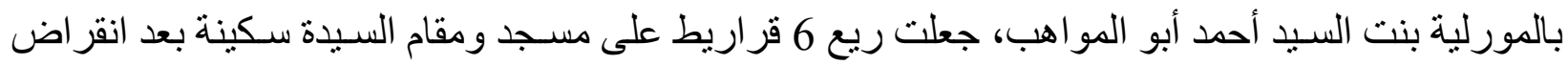

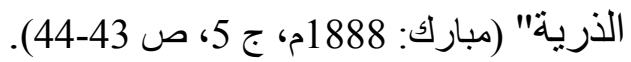

ونختم حديثنا عن مسـاجد آل البيت بمســد السـيدة عائشـة النبوية رضـي الله عنها، يقع خارج ميدان محمد علي عن شمال الذاهب إلى القرافة الصغرى، وهي السيدة عائشة بنت جعفر الصادق بن محمد الباقر بن

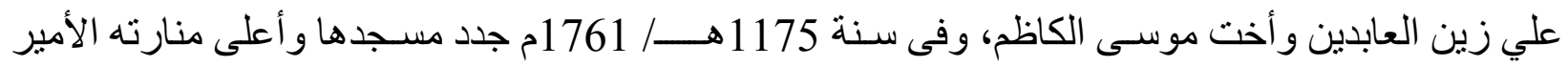

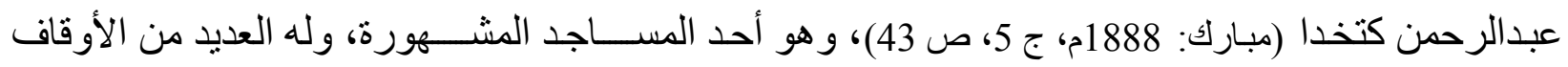

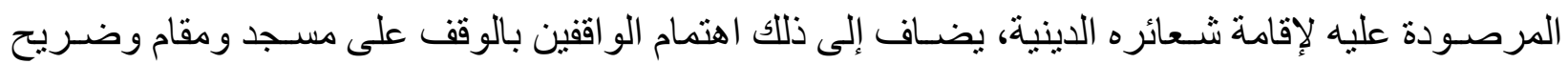
السـيدة الثـريفة رقية رضـي الله عنها بنت الإمام علي، الكائن بخط الخليفة بمصـر المحروسـة (وزارة الأوقاف:

1278هـ، حجة 114).

كان لكل مساجد آل البيث أضرحة ومقامات، عليها من المهابة و الجلال فى قلوب عامة المصريين ما

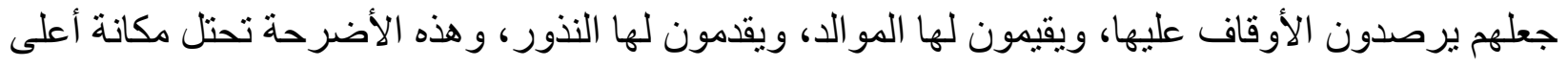

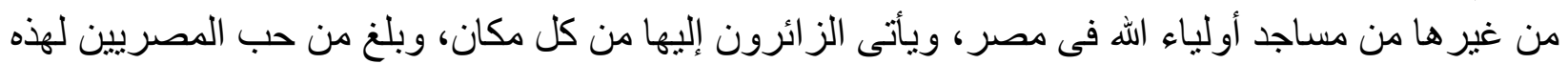

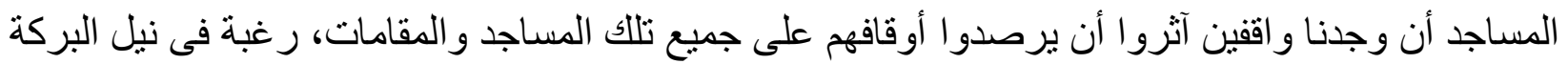
و التقرب منهم حتى و إن لم يكونو ا مصربين فى الأصل، لكنهم تأثروا بهم على اعتبار أنهم مسلمون كالمعاتيق

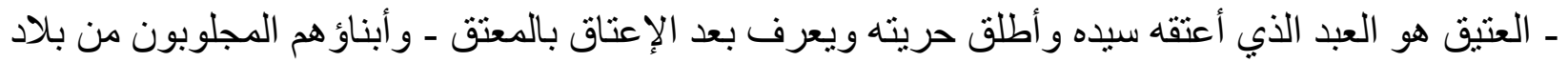
شرق آسياو البلاد التركية، كوقف "فخر المخدرات وتاج المستور ات ذات الحجاب الرفيع، الست فاطمة خاتون بنت عبداله البيضا معتوقة المرحوم محمد أغا مر اد الكبير"، و هو عبارة عن "جميع أطيان أوسية التزام قدر ها لئ

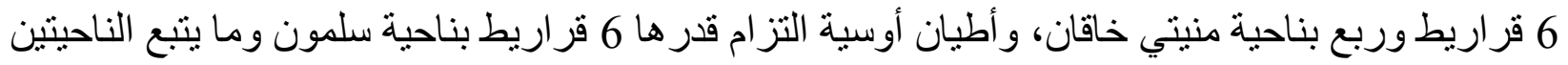
من الفايظ .."، وقفت ذللك على نفسها ثم على "إقامة شعائر ومهمات مسجد ومقام وضريح الإمام الحسين، وفئ و السيدة الثريفةزينب، و السيدة الثريفة سكينة، والسيدة الشريفة رقية رضي الله عنهم أجمعين" (وزارة الأوقاف: 1278 هـ، حجة 114).

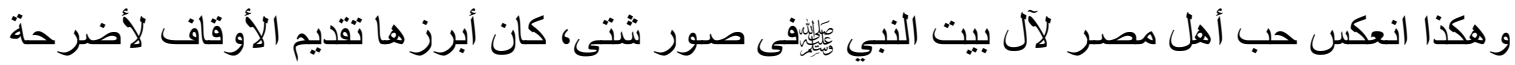

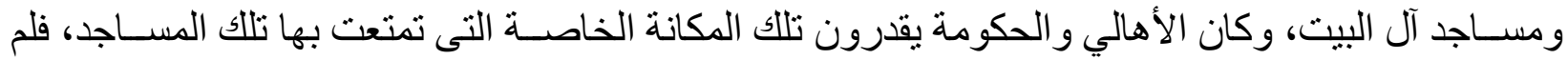

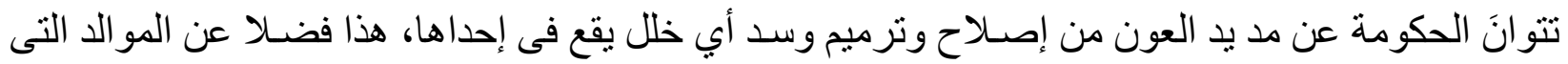

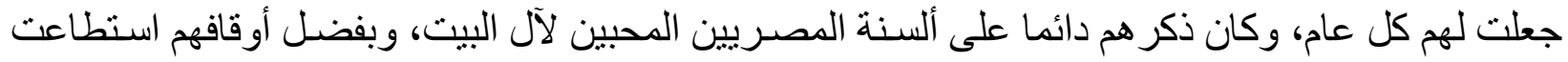

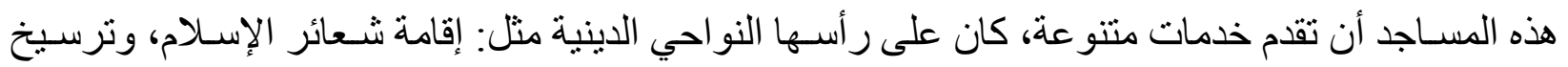


مبدأ التقرب من أهل البيت، وخدمات تعليمية؛ مثل إلقاء الدروس، ونشـــر العلوم النقلية بفروعها المختلفة،

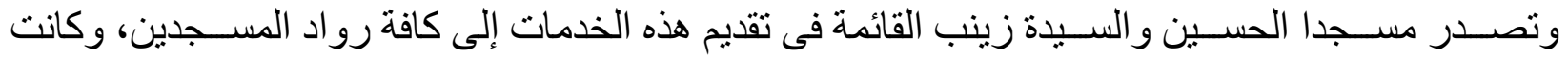

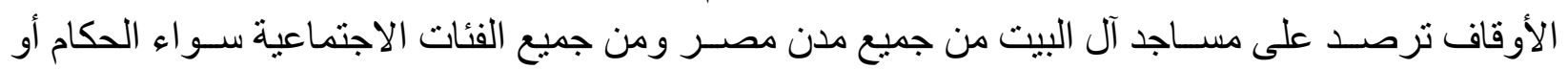

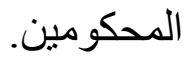

\section{خاتمة}

من خلال هذا البحث نستطيع الوقوف على عدة حقائق توضح أهية الوقف على المساجد، وقد تمثلت

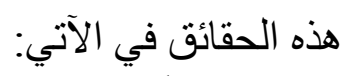

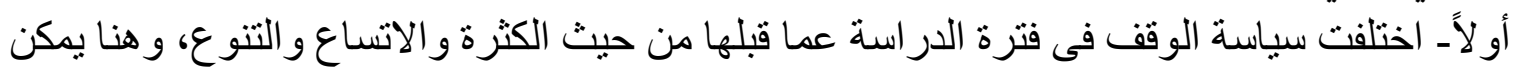

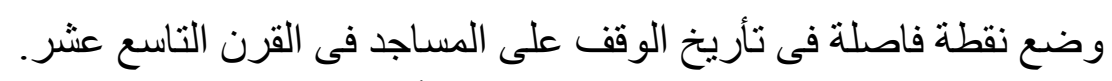

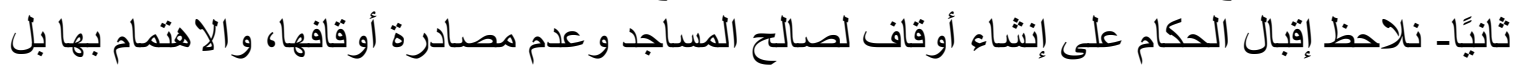

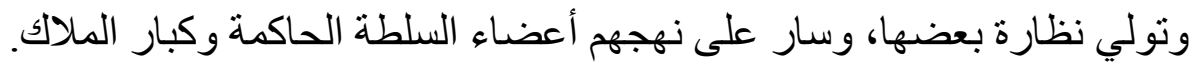

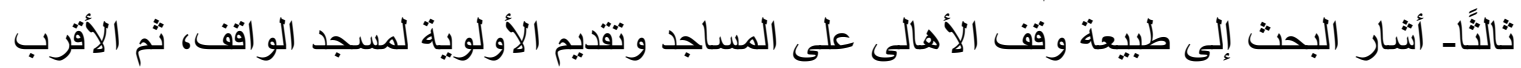

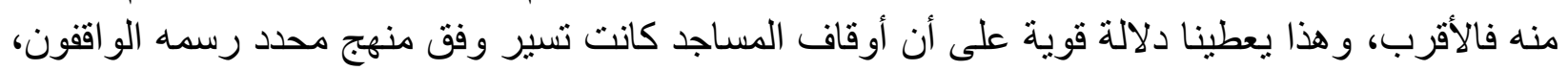

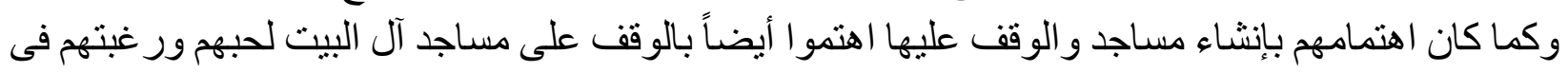

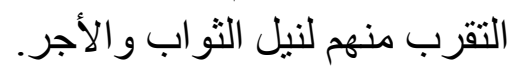
رابعًا- لم تحتكر فئة معينة من الوأ اقفين إنشاء الأوقاف على المساجد، بل شاركت جميع فئات المجتمع فيه سواء الذكور أو الإناث وحتى العتى فئناء.

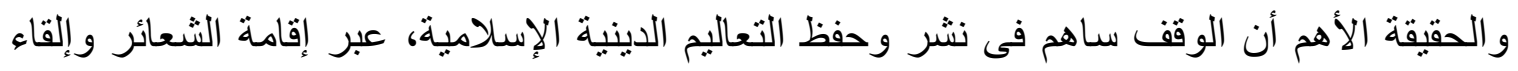

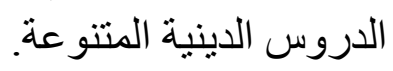
ونأمل أن يفتح هذا البحث المجال لدار استات أخرى لأوقاف المساجد، كتحديد نو عية منهاو اتخاذها محلاً للار اسة، كأوقاف مساجد الأولياء على سبيل المثنال. 
قائمة المصادر والمراجع

أولا: الوثائق غير المنشورة.

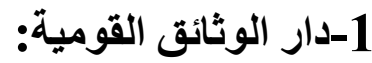

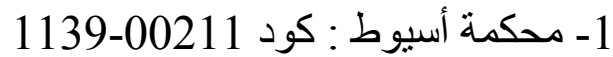

2- مديرية البحرين: كود

3- محافظ الأبحاث: محفظة 131 - محفظة 127

4- أدر اج الدار: درج 82

2: أرشيف وزارة الأوقاف:

حجة 114

حجة 1152

حجة 176

حجة 217

حجة 353

حجة

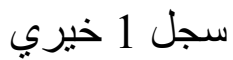

سجل 1 قديم

سجل 10 قبلي

سجل 11 قبلي

سجل 11 مصر

سجل 2 خيري

سجل 3 خيري

سجل 35 أهلى

سجل 5 خيري قديم

سجل 8 بحرى

ملف 2815

ملف 500

ملف 5500

ملف 5833

ملف 7063

ثانيا: الوثائق المنشورة: 
كتاب - حجة ـ وقف أحمد باثنا المنشاوى: 22 أكتوبر 1903م، مطبعة وزارة الأوقاف، 1945م ثالثا: المصادر:

1. إبر اهيح, أحمد: 1937م، أحكام الأوقاف والمواربث، القاهرة، المطبعة السلفية.

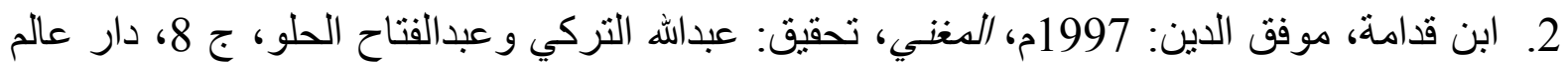

3. ابن منظور: (د ت)، لسان العرب، ج 6، القاهرة.

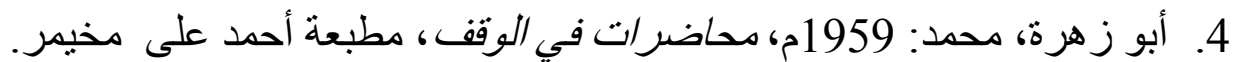

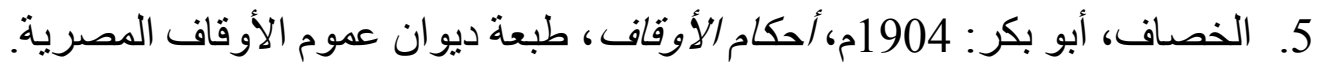

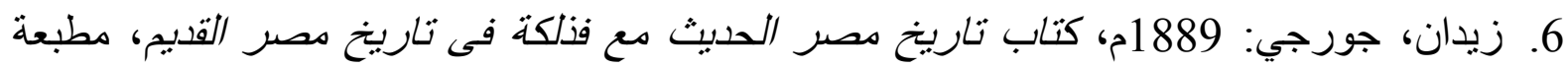
المقتطف. زئن جنان.

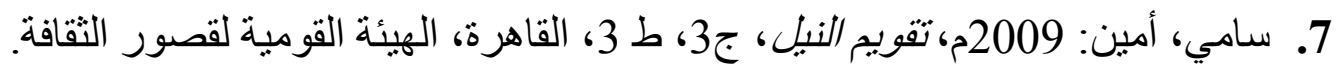

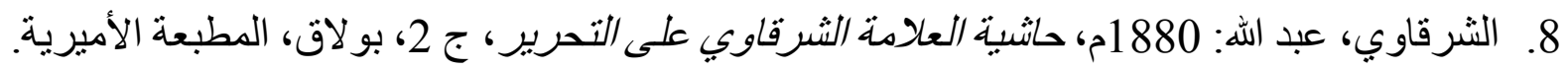

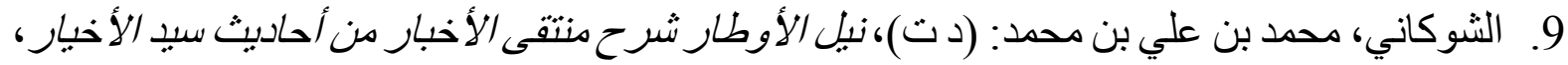

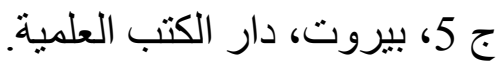

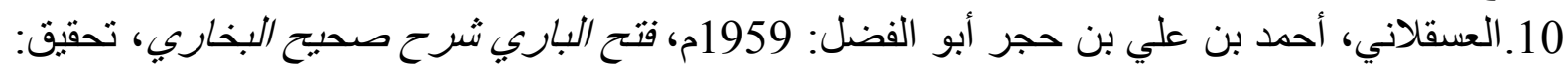

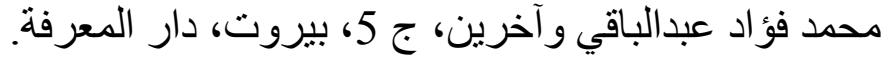

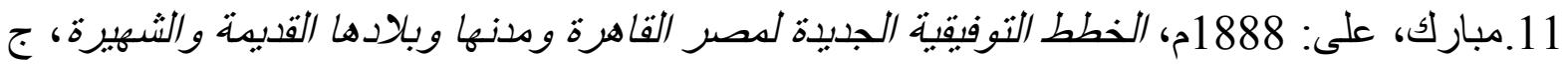

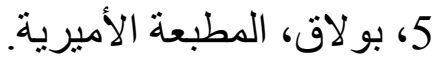

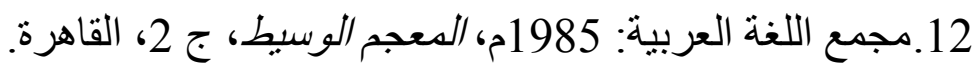
13.المقرى، شرف الدين: (د ت)، كتاب التهشية بشرح إرشاد الغاوي في مسلك الحاوي، الحفية تحقيق: محمود

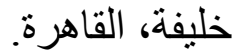
14.المهدى، محمد العباسى: 1883مه الفتاوى، ج 2، ط 1، 1، المطبعة الأزهرية المصرية.

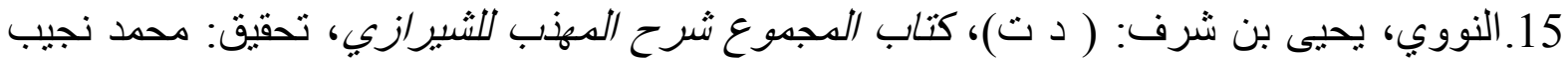

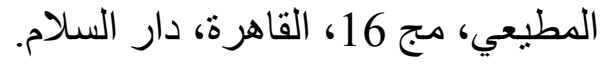




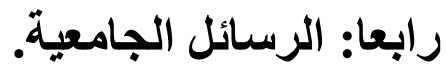

على، مصفى محمود: 2015م، الأوقاف ودور ها فى الثقافة والثتعليم فى عصر محدد على، رسالة ماجستير غير منشورة - كلية الآداب - جامعة القاهرة.

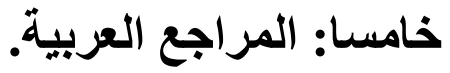

1. إسماعيل، محمد حسام الدين: 1997م، مدينة القاهرة من ولاية محمد على إلى إسماعيل 1805-

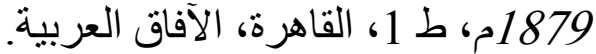

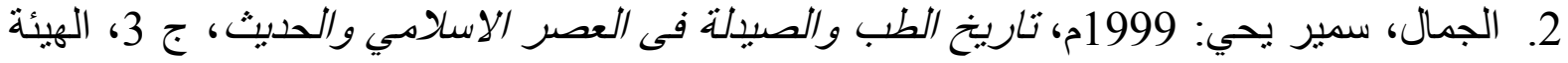

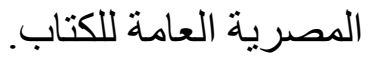

3. حسب الله، علي: 1956م، خلاصة أحكام الوقف في الفقه الاسلامي، القاهرة، مطبعة لجنة البيان العربي. 4. غانم، إبر اهيم البيومي: 1998م، الأوقاف والسياسة فى مصر، ط 1977، دار الثروق. 5. الكبيسي، محمد عبيد عبد الله: 1977م، أحكام الوقف في الثيد الشريعة الإسلامية، ج 1، بغداد، مطبعة

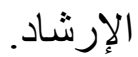

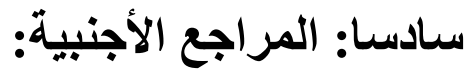
1-Al-Asad, Mohammad: 1992, The Mosque of Muhammad Ali in Cairo muqarnas, vol, 9 


\title{
Endowments for mosques in Egypt 1849-1913 AD
}

\author{
Mostafa Mahmoud Ali \\ PhD researcher
}

History Department - Facutly of women- Ain Shams University

Mostafa_435@yahoo.com

Supervision

Prof. Dr. Mohamed Afifi Abdel Khaleq

Professor of Modern and Contemporary History - Cairo University

A.pr.DR/ Khalaf Abdul Azim Al-Miri

Professor of Modern and Contemporary History - Facutly of women- Ain Shams University

\begin{abstract}
:
The endowment is considered the mainstay of religious life, as it provided the mosques with all their needs and provided them with the necessary expenses to fulfill their mission, which led to the strengthening of religious sentiment, and from here the field of worship was the focus of attention of those standing in different social affiliations and economic levels. One of the aspects of reviving the rituals of religion, and this research sheds light on the role of the endowment in religious life, especially the endowment on mosques between 1849 AD - 1913 AD, through four elements: The first: It talks about authority and endowments over mosques, The second: deals with the role of members of the ruling authority in the endowment of mosques, the third: the endowment of the people in the establishment of mosques, and the fourth: the endowment over the mosques of Ahl al-Bayt. The research concluded with several results, the most prominent of which were: clarifying the role of the endowment in the establishment of mosques, highlighting the social groups on which endowments were monitored, and the researcher followed the method of analytical historical research that relies on dealing with and analyzing events, and monitoring the changes that occurred in the endowment process during the research period.
\end{abstract}

Key words : Endowments , Mosques, Ismail,. Documentation , Al-Bayt 